\title{
A New Heterobinuclear Fe"l'Cu" Complex with a Single Terminal Fe'III-O(phenolate) Bond. Relevance to Purple Acid Phosphatases and Nucleases
}

\author{
Mauricio Lanznaster ${ }^{1}$, Ademir Neves ${ }^{1}$, Adailton J. Bortoluzzi ${ }^{1}$, \\ Veronika V. E. Aires ${ }^{1}$, Bruno Szpoganicz ${ }^{1}$, Hernán Terenzi ${ }^{2}$, \\ Patricia Cardoso Severino ${ }^{2}$, Julie M. Fuller ${ }^{4}$, Simon C. Drew ${ }^{3}$, \\ Lawrence R. Gahan ${ }^{4}$, Graeme R. Hanson ${ }^{3}$, Mark J. Riley ${ }^{4}$ and \\ Gerhard Schenk ${ }^{4}$
}

(1) LABINC Laboratório de Bioinorgânica e Cristalografia, Departamento de Química, Universidade Federal de Santa Catarina, Campus Trindade, 88040-900 Florianópolis, SC, Brazil

(2) Laboratório de Expressão Gênica, Departamento de Bioquímica, Universidade Federal de Santa Catarina, Campus Trindade, 88040-900 Florianópolis, SC, Brazil

(3) Centre for Magnetic Resonance, The University of Queensland, St. Lucia, QLD, 4072, Australia

(4) Department of Chemistry, School of Molecular and Microbial Sciences, The University of Queensland, St. Lucia, QLD, 4072, Australia

\begin{abstract}
A novel heterobinuclear mixed valence complex $\left[\mathrm{Fe}^{\mathrm{III}} \mathrm{Cu}^{\mathrm{II}}(\mathrm{BPBPMP})(\mathrm{OAc})_{2}\right] \mathrm{ClO}_{4}, \mathbf{1}$, with the unsymmetrical $\mathrm{N}_{5} \mathrm{O}_{2}$ donor ligand 2-bis[ $\{(2$-pyridylmethyl $)$ aminomethyl $\}-6-\{(2-$ hydroxybenzyl)(2-pyridylmethyl)\}aminomethyl]-4-methylphenol ( $\mathrm{H}_{2} \mathrm{BPBPMP}$ ) has been synthesized and characterized. A combination of data from mass spectrometry, potentiometric titrations, X-ray absorption and electron paramagnetic resonance spectroscopy, as well as kinetics measurements indicates that in ethanol/water solutions an $\left[\mathrm{Fe}^{\mathrm{III}}-(\mu) \mathrm{OH}-\mathrm{Cu}^{\mathrm{II}} \mathrm{OH}_{2}\right]+$ species is generated which is the likely catalyst for 2,4-bis(dinitrophenyl)phosphate and DNA hydrolysis. Insofar as the data are consistent with the presence of an $\mathrm{Fe}^{\mathrm{III}}$-bound hydroxide acting as a nucleophile during catalysis, 1 presents a suitable mimic for the hydrolytic enzyme purple acid phosphatase. Notably, $\mathbf{1}$ is significantly more reactive than its isostructural homologues with different metal composition $\left(\mathrm{Fe}^{\mathrm{III}} \mathrm{M}^{\mathrm{II}}\right.$, where $\mathrm{M}^{\mathrm{II}}$ is $\mathrm{Zn}^{\mathrm{II}}, \mathrm{Mn}^{\mathrm{II}}, \mathrm{Ni}^{\mathrm{II}}$, or $\left.\mathrm{Fe}^{\mathrm{II}}\right)$. Of particular interest is the observation that cleavage of double-stranded plasmid DNA occurs even at very low concentrations of $1(2.5 \mu \mathrm{M})$, under physiological conditions (optimum $\mathrm{pH}$ of 7.0), with a rate enhancement of $2.7 \times 10^{7}$ over the uncatalyzed reaction. Thus, $\mathbf{1}$ is one of the most effective model complexes to date, mimicking the function of nucleases.
\end{abstract}

Electronic Supplementary Material Supplementary material is available for this article at http://dx.doi.org/10.1007/s00775-005-0635-7.

Keywords heterobinuclear $\mathrm{Fe}^{\mathrm{III}} \mathrm{Cu}^{\mathrm{II}}$ complex; purple acid phosphatase; phosphate diester hydrolysis; DNA cleavage; EPR; XAS

\section{Introduction}

Purple acid phosphatases (PAPs) constitute a class of metalloenzymes that are able to catalyze the hydrolysis of a variety of phosphoric acid esters and anhydrides within the $\mathrm{pH}$ range 4-7 [1-4]. The PAPs have been isolated from various mammalian sources, including bovine [5], pig [6], rat and mouse [7, 8], as well as multiple human tissues [9-11]. Animal PAPs, owing to their resistance towards inhibition by tartrate are also referred to as tartrate-resistant acid phosphatases [12], contain redox-active $\mathrm{Fe}^{\mathrm{III}} \mathrm{Fe}^{\mathrm{II} / \mathrm{III}}$ binuclear active sites where only the reduced form is catalytically active. In contrast, all plant PAPs characterized to date either contain redox-inactive $\mathrm{Fe}^{\mathrm{III}} \mathrm{Zn}^{\text {II }}$ (red kidney bean PAP [13], one isoform of sweet potato [14] and soybean PAP [1]) or Fe ${ }^{\mathrm{III}} \mathrm{Mn}^{\mathrm{II}}$ (another sweet potato isoform [1]) centers. A fungal PAP has also been isolated from Aspergillus niger [15] but its metal composition has not been determined. No bacterial PAP has yet been studied; however, by sequence analysis and 
homology modeling it was found that PAPs may only occur in a limited number of bacterial organisms $[16,17]$.

The crystal structures of PAPs from pig [18], rat [19, 20], red kidney bean [21, 22] and the FeMn isoform from sweet potato $[23,24]$ have been determined and reveal a similar coordination environment around the metal centers. In red kidney bean PAP (resolution $2.65 \AA$ ) the $\mathrm{Fe}^{\mathrm{III}}$ ion is coordinated by a tyrosine $\left(\mathrm{Y}_{167}\right.$; donor for the ligand-to- $\mathrm{Fe}^{\mathrm{III}}$ charge transfer transition), a histidine $\left(\mathrm{H}_{325}\right)$ and an aspartate $\left(\mathrm{D}_{135}\right)$, while the $\mathrm{Zn}^{\mathrm{II}}$ is coordinated by two histidines $\left(\mathrm{H}_{286}, \mathrm{H}_{323}\right)$ and an asparagine $\left(\mathrm{N}_{201}\right)[21,22]$. The $\mathrm{Fe}^{\mathrm{III}} \mathrm{Zn}^{\mathrm{II}}$ core is bridged by a monodentate carboxylate group of an aspartate $\left(\mathrm{D}_{164}\right)$ and by a modeled $\mu$-hydroxo group. Terminal aqua and hydroxo ligands were also modeled to complete the coordination spheres of the $\mathrm{Fe}^{\mathrm{III}}$ and $\mathrm{Zn}^{\mathrm{II}}$ ions, respectively, resulting in the $\left[(\mathrm{OH}) \mathrm{Fe}^{\mathrm{III}}-\mu(\mathrm{OH})-\mathrm{Zn}^{\mathrm{II}}\left(\mathrm{OH}_{2}\right)\right]$ core [22].

For pig, bovine and red kidney bean PAP it could be demonstrated that enzyme activity can be reconstituted by a variety of $M^{\mathrm{III}} M^{\mathrm{II}}$ combinations, where $M^{\mathrm{III}}$ can be $\mathrm{Fe}^{\mathrm{III}}, \mathrm{Ga}^{\mathrm{III}}$ or $\mathrm{Al}^{\mathrm{III}}$, and $M^{\mathrm{II}}$ is either $\mathrm{Fe}^{\mathrm{II}}, \mathrm{Zn}^{\mathrm{II}}, \mathrm{Mn}^{\mathrm{II}}, \mathrm{Co}^{\mathrm{II}}, \mathrm{Cd}^{\mathrm{II}}, \mathrm{Ni}^{\mathrm{II}}$ or $\mathrm{Cu}^{\mathrm{II}}[5,25-29]$. In contrast, the FeMn isoform of sweet potato PAP appears to be more specific, at least in terms of the divalent metal ion; only $\mathrm{Mn}^{\text {II }}$ is effective in reconstituting activity [30]. This enzyme is distinguished from other PAPs also by its increased catalytic rate, its broader substrate specificity and the $\mathrm{pH}$-dependence of its catalytic parameters $[1,30]$. Some of these observed differences are interpreted in terms of a more potent nucleophile in the sweet potato enzyme $[24,30]$. However, the precise mechanism of PAP-catalyzed reactions, and the contribution of the two metal ions to reactivity, remain unknown.

Since PAPs and related protein phosphatases are central to various aspects in metabolism (e.g., bone metabolism, signal transduction) [31], and, in particular, since PAPs have become a target for the synthesis of chemotherapeutics against bone-related disorders $[12,32]$, there is strong interest to generate and study low molecular weight complexes which mimic the properties of the various heterobinuclear and heterovalent metal centers that occur in PAPs and related proteins. Recently, we have established a general method for the preparation of mixed-valence homobinuclear and heterobinuclear $M^{\mathrm{III}} M^{\mathrm{II}}$ complexes using the unsymmetrical donor ligand 2-bis[ $\{(2$-pyridylmethyl)aminomethyl $\}-6-\{(2$-hydroxybenzyl $)(2-$ pyridylmethyl)\} aminomethyl]-4-methylphenol ( $\left.\mathrm{H}_{2} \mathrm{BPBPMP}\right)$ [33-38]. The synthesized $\mathrm{Fe}^{\mathrm{III}} \mathrm{Fe}^{\mathrm{II} / \mathrm{III}}$ [37], $\mathrm{Fe}^{\mathrm{III}} \mathrm{Zn}^{\mathrm{II}}$ [36], $\mathrm{Fe}^{\mathrm{III}} \mathrm{Mn}^{\mathrm{II}}$ [34], $\mathrm{Mn}^{\mathrm{III}} \mathrm{Mn}^{\mathrm{II}}$ [35] and $\mathrm{Fe}^{\mathrm{III}} \mathrm{Ni}^{\mathrm{II}}$ [33] complexes contain the $\mathrm{Fe}^{\mathrm{III}}$ phenolate motif characteristic for the visible (purple) chromophore. Herein we describe the synthesis and spectroscopic characterization of an $\mathrm{Fe}^{\mathrm{III}} \mathrm{Cu}^{\mathrm{II}}$ complex, using the $\mathrm{H}_{2} \mathrm{BPBPMP}$ ligand. Although several heterobinuclear $\mathrm{Fe}^{\mathrm{III}} \mathrm{Cu}^{\mathrm{II}}$ model complexes have been reported previously [39-42] none of these contain the previously mentioned chromophore and, importantly, do not hydrolyze phosphate esters. The complex described here, $\left[\mathrm{Fe}^{\mathrm{III}} \mathrm{Cu}^{\mathrm{II}}(\mathrm{BPBPMP})(\mathrm{OAc})_{2}\right]\left[\mathrm{ClO}_{4}\right] \cdot \mathrm{H}_{2} \mathrm{O}(\mathbf{1})$, displays high efficiency towards the activated substrate 2,4-bis(dinitrophenol)phosphate (2,4-BDNPP) and, interestingly, is also very proficient in the cleavage of plasmid DNA under physiological conditions and at very low concentrations of $\mathbf{1}$, indicating its potential as a chemical nuclease.

\section{Materials and methods Synthesis of 1}

Complex 1 was synthesized by addition of $\mathrm{Cu}(\mathrm{OAc})_{2} \cdot 2 \mathrm{H}_{2} \mathrm{O}(0.5 \mathrm{mmol})$ to a methanolic solution of the $\mathrm{H}_{2} \mathrm{BPBPMP}$ ligand [34] $(0.5 \mathrm{mmol})$ followed by a drop-by-drop addition of a methanolic solution of $\mathrm{Fe}\left(\mathrm{ClO}_{4}\right)_{3} \cdot 9 \mathrm{H}_{2} \mathrm{O}(0.5 \mathrm{mmol})$. Finally, $0.5 \mathrm{mmol} \mathrm{NaOAc} \cdot 3 \mathrm{H}_{2} \mathrm{O}$ was added and the purple solution obtained was stirred at $50^{\circ} \mathrm{C}$ for $30 \mathrm{~min}$. After leaving the solution for a few days at room temperature, a solid was isolated and recrystallized in acetone/ethyl acetate 1:1, yielding a crystalline solid suitable for X-ray analysis. The calculated (using $\mathrm{C}_{38} \mathrm{H}_{41} \mathrm{ClCuFeN}_{5} \mathrm{O}_{11}$ with a formula weight of $898.60 \mathrm{~g} \mathrm{~mol}^{-1}$ ) and experimental contents (in percent) of carbon, hydrogen and nitrogen atoms in $\mathbf{1}$ are C 50.83, H 4.61, N 7.80 (calculated) and C 50.21, H 4.46, N 7.66 (experimental), respectively. Caution! Perchlorate salts of metal complexes are potentially explosive and therefore should be prepared in small quantities. 


\section{X-ray crystallographic analysis}

Spacegroup: monoclinic (P2 $1 / \mathrm{n})$ with $a=12.831(5), b=18.249(5), c=16.891(5) \AA$ and $\beta=$ 93.97(1) $)^{\circ}, \mathrm{V}=3946(2) \AA^{3}, \mathrm{Z}=4, \mathrm{D}_{\text {calc }}=1.513 \mathrm{~g} \mathrm{~cm}^{-3}, \mu=1.041 \mathrm{~mm}^{-1}$ and $\mathrm{F}(000)=1,856 ; 6,879$ collected reflections; goodness-of-fit 1.043; extinction coefficient 0.0004(3); highest residual electron density $0.757 \mathrm{e} \AA^{-3}$. An irregularly shaped dark purple crystal of $\mathbf{1}$ with dimensions of $0.43 \times 0.40 \times 0.26 \mathrm{~mm}$ was selected for the crystallographic analysis. The data collection was carried out with a CAD-4 diffractometer equipped with graphite-monochromated Mo Ka radiation $(\lambda=0.71069 \AA)$ using the $\omega$ - $2 \theta$ scan method, at room temperature. Data reduction was performed with HELENA [43] and empirical absorption correction ( $\psi$-scan, $T_{\max }=0.763$ and $T_{\min }=0.691$ ) was performed with PLATON [44]. The structure was solved by direct methods and refined by full-matrix least-squares methods using SHELXS97 [45] and SHELXL97 [46] programs, respectively. Non-hydrogen atoms were refined with an anisotropic displacement parameter, except for the oxygen atoms of the perchlorate counterion, which were refined isotropically. Two oxygen atoms in the perchlorate group are disordered, where each of the oxygen atoms are in two alternative positions with site occupancies of 0.61(1) and 0.38(1). Hydrogen atoms of the water molecule were found from the Fourier map, whereas the other hydrogen atoms were placed at idealized positions using standard geometric criteria. The final refinement involving 6,576 $\left(R_{\text {int }}=0.016\right)$ unique reflections and 504 parameters converged to final indices $R_{1}=0.0429$ and $w R_{2}=0.1150$ for $4,744$ observed reflections [I $>2 \sigma(\mathrm{I})]$ and $R_{1}=0.0800$ and $w R_{2}=0.1299$ for all data. The ZORTEP program [47] was used to make a perspective view of the molecular structure. CCDC-222725 contains the supplementary crystallographic data for this paper. These data can be obtained free of charge at http://www.ccdc.cam.ac.uk/conts/retrieving.html (or from the Cambridge Crystallographic Data Centre, 12 Union Road, Cambridge CB2 1EZ, UK; Fax: +44-1223-336033; e-mail: deposit@ccdc.cam.ac.uk).

\section{Mass spectrometry}

Samples for mass spectrometry were prepared in an ethanol/water mixture (70:30\%) in small sample tubes just prior to injection of the sample into an atmospheric pressure ionization source of a Finnigan MAT 900 XL-Trap double-focusing-sector mass spectrometer with a Finnigan API III electrospray ionization source. The capillary voltage was $-8.2 \mathrm{~V}$ and the skimmer voltage $8.2 \mathrm{~V}$.

\section{Potentiometric titrations and square-wave voltammetry}

The potentiometric studies were carried out with a Corning-350 research $\mathrm{pH}$ meter fitted with blue-glass and $\mathrm{Ag} / \mathrm{AgCl}$ reference electrodes. Doubly distilled water in the presence of $\mathrm{KMnO}_{4}$ and reagent grade ethanol was used to prepare the ethanol/water $(70: 30 ; \mathrm{v} / \mathrm{v})$ solutions. The electrode and the $\mathrm{pH}$ meter were calibrated using the data obtained from a potentiometric titration of a known volume of a standard ethanol/water $0.100 \mathrm{M} \mathrm{HCl}$ solution with a standard ethanol/water $0.100 \mathrm{M} \mathrm{KOH}$ solution. The ionic strength of the $\mathrm{HCl}$ solution was maintained at $0.100 \mathrm{M}$ by addition of $\mathrm{KCl}$. The measurements were carried out in a thermostated cell containing a complex solution $(0.05 \mathrm{~mol} / 50 \mathrm{ml})$ with ionic strength adjusted to $0.100 \mathrm{M}$ by addition of $\mathrm{KCl}$, at $25.00 \pm 0.05^{\circ} \mathrm{C}$. All experimental solutions were prepared in ethanol/water $(70: 30 ; \mathrm{v} / \mathrm{v})$ owing to the low solubility of the complex in water. The experiments were performed under argon flow to eliminate the presence of atmospheric $\mathrm{CO}_{2}$. The samples were titrated by addition of fixed volumes of a standard $\mathrm{CO}_{2}$-free ethanol/water $\mathrm{KOH}$ solution $(0.100 \mathrm{M})$. Computations were carried out with the BEST7 program, and species diagrams were obtained with SPE and SPEPLOT programs [48].

Square-wave voltammograms were performed with a Princeton Applied Research (PAR; TN, USA) 273 system at room temperature under an argon atmosphere. These experiments were carried out employing a standard three-component system: a carbon-glass working electrode, a platinum-wire auxiliary electrode and an $\mathrm{Ag} / \mathrm{Ag}$ pseudoreference electrode constructed in our laboratory. To monitor the reference electrode, the 
ferrocenium/ferrocene couple was used [49]. The supporting electrolyte was $0.1 \mathrm{M}$ tetrabutylammonium hexafluorophosphate $\left(\mathrm{n}-\mathrm{Bu}_{4} \mathrm{NPF}_{6}\right)$.

\section{Spectroscopic measurements}

Electronic absorption spectra of $\mathbf{1}$ in the range $180-800 \mathrm{~nm}$ were recorded with a PerkinElmer L19 spectrophotometer at room temperature $([\mathbf{1}]=0.3 \mathrm{mM})$.

X-ray absorption spectroscopy (XAS) data collection was performed at KEK, Tsukuba, beamline BL-20B. Data were collected for powdered samples diluted in boron nitride in both transmission (approximately $0.2 \mathrm{M}$ ) and fluorescence (approximately $0.02 \mathrm{M}$ ) modes and in a frozen ethanol/water (70:30\%) solution at a concentration of $2 \mathrm{mM}$ in fluorescence mode. All samples were mounted in a closed-cycle helium cryostat and cooled to $10 \mathrm{~K}$. The data for the $\mathrm{K}$ edge of both $\mathrm{Fe}$ and $\mathrm{Cu}$ scans were collected in three regions: preedge, edge and extended X-ray absorption fine structure (EXAFS). A $0.2-\mathrm{keV}$ pre-edge range for $\mathrm{Fe}(6.89-7.09 \mathrm{keV})$ and $\mathrm{Cu}(8.77-8.97 \mathrm{keV})$ contained 20 steps with 2-s integration. The edge ranges were $0.05 \mathrm{keV}(7.09-7.15 \mathrm{keV}$; 241 steps, 2-s integration) and $0.06 \mathrm{keV}$ (8.97$9.02 \mathrm{keV} ; 200$ steps, 2-s integration) for $\mathrm{Fe}$ and $\mathrm{Cu}$, respectively. Data were further collected to $16 \AA^{-1}$ in 320 steps equally separated in k-space, where the integration was ramped from 2 to $20 \mathrm{~s}$ per point. The final energies for the $\mathrm{Fe}$ and $\mathrm{Cu}$ scans were 8.13 and $10.0 \mathrm{keV}$, respectively. Ion chamber detectors were used to monitor the incident beam, calibration and detection for transmission, while a ten-element Ge array was used for fluorescence detection. The spectra were calibrated to the first inflection point of the appropriate metal foil and a total of 4, 8 and 23 spectra were averaged for data collected in the transmission, solid fluorescence and solution fluorescence modes, respectively. Atomic background was subtracted from the averaged data using the AUTOBK feature of the Athena (version 0.8) software package [50]. The theoretical photoelectron scattering amplitudes and phase shifts were calculated using FEFF6 [51] and the theoretical EXAFS signal was fitted to experimental data using the methods implemented in IFEFFIT (version 1.2.5) [52] and Artemis (version 0.7) [50].

Continuous wave electron paramagnetic resonance (EPR) spectra were recorded with a Bruker Elexsys E500 continuous wave spectrometer fitted with an X-band Super High Q cavity. Calibration of the magnetic field and microwave frequency were achieved with a Bruker ER $035 \mathrm{M}$ Gaussmeter and an EIP 548B microwave frequency counter, respectively. Liquid helium temperatures $(1.5-130 \mathrm{~K})$ were obtained with an Oxford ESR910 flow-through cryostat in conjunction with an Oxford Instruments ITC-4 temperature controller.

Spectrometer tuning, signal averaging and subsequent spectral comparisons and plotting were performed with Bruker's Xepr (version 2.2b.38) software.

Computer simulation of the EPR spectra was performed using XSophe (Version 1.1.4) running on a PC with the Mandrake Linux (version 9.1) operating system [53]. The computational program, SOPHE, employs a number of methods, including matrix diagonalization, SOPHE interpolation and homotopy for the analysis of randomly oriented EPR spectra. In this research we employed matrix diagonalization in conjunction with the mosaic misorientation linewidth model [53] to simulate the EPR spectra from randomly oriented samples. This method significantly reduces the computational times. Comparisons of simulated and experimental spectra and data manipulation were performed with Xepr.

\section{DNA cleavage}

DNA cleavage was performed as described elsewhere [54, 55]. The reaction was performed in a final volume of $20 \mu$ containing $1 \mu \mathrm{g}$ pBSK II plasmid DNA, $160 \mu \mathrm{M} 1$ and $25 \mathrm{mM} 3-(N-$ morpholino)propanesulfonic acid (MOPS), $\mathrm{pH}$ 7.0. The reaction mixtures were incubated at $37^{\circ} \mathrm{C}$ for $3 \mathrm{~h}$. Samples were submitted to agarose gel electrophoresis and stained with ethidium bromide. The resulting gels were digitalized with a photodocumentation system (UVP, CA, USA) and DNA bands were quantified using LabWorks software version 4.0 (UVP). 


\section{Anaerobic DNA cleavage}

A two-step procedure $[55,56]$ was used to obtain deoxygenated water, MOPS buffer and EDTA. All solutions and reaction mixtures used were prepared in an argon-filled glovebag. The reactions were performed in a final volume of $20 \mu \mathrm{l}$ containing $1 \mu \mathrm{g}$ pBSK II plasmid DNA, $160 \mu \mathrm{M} 1$ and $25 \mathrm{mM}$ MOPS pH 7.0. The reaction mixtures were incubated at $37^{\circ} \mathrm{C}$ for $3 \mathrm{~h}$ in a sealed argon-filled vacuum desiccator. All other conditions and procedures were essentially the same as those described for aerobic reactions (vide supra).

\section{Kinetics assays}

Phosphatase-like activity was determined under conditions with an excess of substrate, 2,4BDNPP [63] as described elsewhere [33, 34, 36].

DNA cleavage reactions were performed at $37^{\circ} \mathrm{C}$ in $25 \mathrm{mM}$ MOPS ( $\mathrm{pH} 7.0$ ), using $90 \mu \mathrm{M}$ (base pair) pBSK II plasmid DNA at concentrations of 1 ranging from 0 to $320 \mu \mathrm{M}$, in a final volume of $250 \mu \mathrm{l}$. Aliquots of $20 \mu \mathrm{l}$ were withdrawn at different time intervals $(0-$ $360 \mathrm{~min}$ ) and were analyzed as described for DNA cleavage.

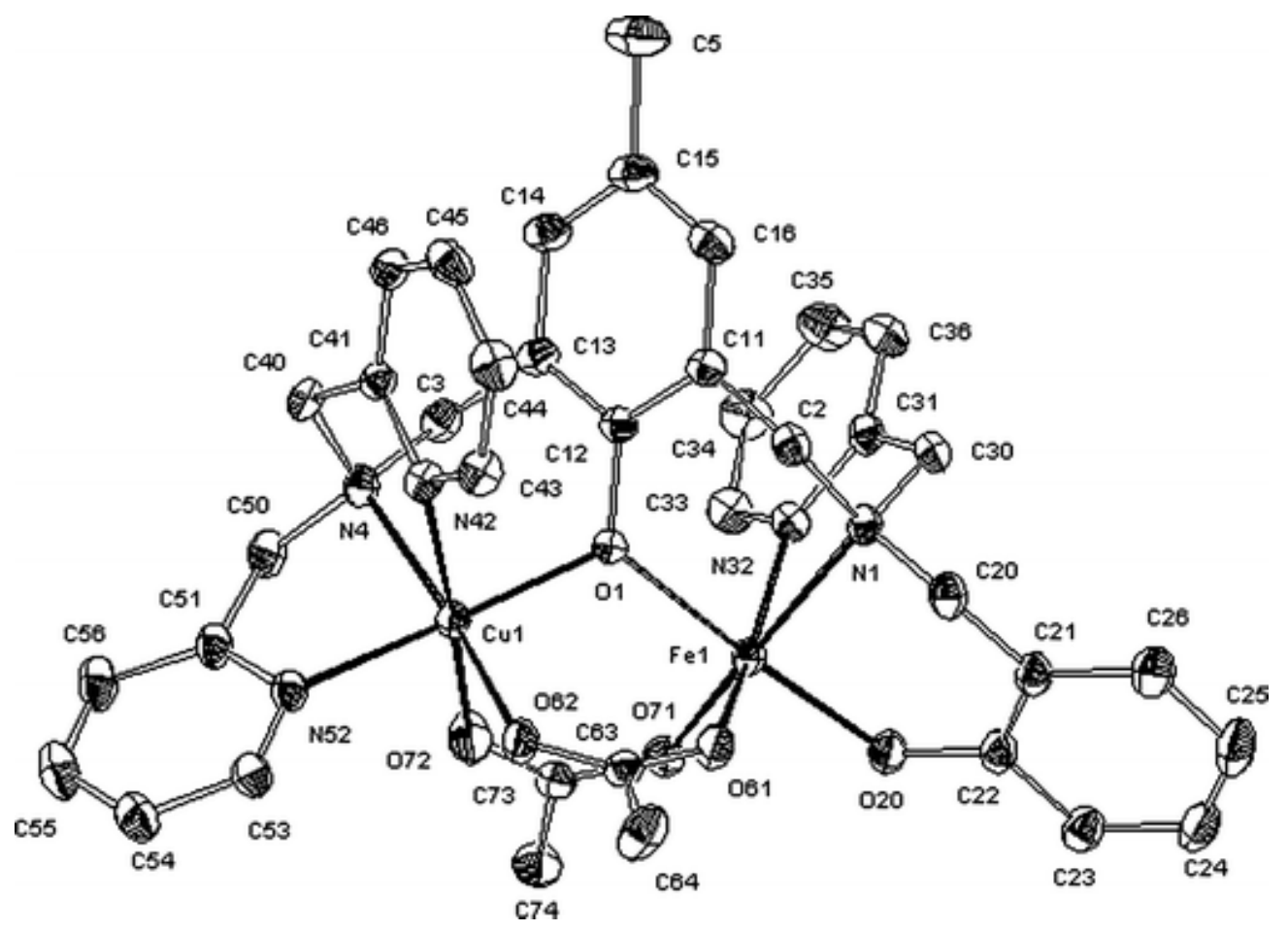

Fig. 1 ZORTEP plot of the cation of $\left.\mathrm{Fe}^{\mathrm{III}} \mathrm{Cu}^{\mathrm{II}}(\mathrm{BPBPMP})(\mathrm{OAc})_{2}\right]\left[\mathrm{ClO}_{4}\right] \cdot \mathrm{H}_{2} \mathrm{O}(\mathbf{1})$ with labeling scheme. The ellipsoids are shown at $40 \%$ probability level. Hydrogen atoms are omitted for clarity.

\section{Results and discussion X-ray crystal structure of 1}

Well-formed dark-purple crystals of $\mathbf{1}$ were obtained by slow evaporation of the solvent from an acetone/ethyl acetate (1:1) solution of the complex. The structure and atomic numbering scheme of 1 are shown in Fig. 1 and selected bond lengths and angles are shown in Table 1. The X-ray structure of 1 reveals a binuclear arrangement of $\left[\mathrm{Fe}^{\mathrm{III}} \mathrm{Cu}(\mathrm{BPBPMP})(\mathrm{OAc})_{2}\right]^{+}$ where the $\mathrm{Fe}^{\mathrm{III}}$ and $\mathrm{Cu}^{\mathrm{II}}$ ions are bridged by the phenolate oxygen $\mathrm{O} 1$ of $\mathrm{BPBPMP}^{2-}$ and by the two carboxylate groups of the acetate ligands. Similar to other $M^{\mathrm{III}} M^{\mathrm{II}}$ binuclear model complexes synthesized using the unsymmetric $\mathrm{BPBPMP}^{2-}$ ligand [33-38] the $\mathrm{N}_{2} \mathrm{O}_{4}$ coordination sphere of $\mathrm{Fe} 1$ is completed by two nitrogen atoms (N1 and N32) of the tertiary amine and the pyridine group, respectively, and the $\mathrm{O} 20$ oxygen of the terminal phenolate (hard side) [40]. The $\mathrm{N}_{3} \mathrm{O}_{3}$ octahedral coordination sphere of $\mathrm{Cu} 1$ is complemented by N4, N42 and N52 nitrogen atoms of the adjacent bis(2-pyridylmethyl)amine pendant arm (soft 
side) [40] of the $\mathrm{BPBPMP}^{2-}$ ligand (Fig. 1). The facial arrangement of the tridentate pendant arms of $\mathrm{BPBPMP}^{2-}$ around the $\mathrm{Fe}^{\mathrm{III}}$ and $\mathrm{Cu}^{\mathrm{II}}$ centers in $\mathbf{1}$ is identical to those observed in the

TABLE 1 Selected bond lengths and angles for $\left.\mathrm{Fe}^{\mathrm{III}} \mathrm{Cu}(\mathrm{BPBPMP})(\mathrm{OAc})_{2}\right]\left[\mathrm{ClO}_{4}\right] \cdot \mathrm{H}_{2} \mathrm{O}$

Bond length ( $\AA$ )

\begin{tabular}{|c|c|c|c|}
\hline Fe1-O20 & $1.902(3)$ & O20-Fe1-O71 & $89.69(15)$ \\
\hline Fe1-O71 & $1.954(3)$ & O20-Fe1-O61 & $89.72(15)$ \\
\hline Fe1-O61 & $2.021(3)$ & O71-Fe1-O61 & $100.73(15)$ \\
\hline Fe1-O1 & $2.035(3)$ & O20-Fe1-O1 & $173.76(14)$ \\
\hline Fe1-N32 & $2.183(4)$ & O71-Fe1-O1 & $96.38(13)$ \\
\hline Fe1-N1 & $2.235(4)$ & O61-Fe1-O1 & $87.75(13)$ \\
\hline $\mathrm{Cu} 1-\mathrm{O} 62$ & $1.968(3)$ & $\mathrm{O} 20-\mathrm{Fe} 1-\mathrm{N} 32$ & $96.26(15)$ \\
\hline $\mathrm{Cu} 1-\mathrm{O} 1$ & $1.989(3)$ & O71-Fe1-N32 & 91.91(15) \\
\hline Cu1-N52 & $2.007(4)$ & O61-Fe1-N32 & $166.06(14)$ \\
\hline Cu1-N4 & $2.078(4)$ & O1-Fe1-N32 & $85.00(13)$ \\
\hline $\mathrm{Cu} 1-\mathrm{O} 72$ & $2.300(4)$ & O20-Fe1-N1 & $87.19(14)$ \\
\hline Cu1-N42 & $2.342(4)$ & O71-Fe1-N1 & $167.48(15)$ \\
\hline \multirow[t]{24}{*}{$\mathrm{Fe} 1-\mathrm{Cu} 1$} & $3.470(1)$ & O61-Fe1-N1 & 91.39(14) \\
\hline & & O1-Fe1-N1 & $87.17(13)$ \\
\hline & & N32-Fe1-N1 & $76.40(14)$ \\
\hline & & O62-Cu1-O1 & $94.09(13)$ \\
\hline & & O62-Cu1-N52 & $93.18(15)$ \\
\hline & & O1-Cu1-N52 & $169.90(14)$ \\
\hline & & O62-Cu1-N4 & $169.84(15)$ \\
\hline & & O1-Cu1-N4 & $92.76(14)$ \\
\hline & & N52-Cu1-N4 & $81.01(16)$ \\
\hline & & O62-Cu1-O72 & $94.68(15)$ \\
\hline & & O1-Cu1-O72 & $88.95(13)$ \\
\hline & & N52-Cu1-O72 & $83.48(14)$ \\
\hline & & N4-Cu1-O72 & $92.93(15)$ \\
\hline & & O62-Cu1-N42 & $92.88(15)$ \\
\hline & & O1-Cu1-N42 & $91.11(13)$ \\
\hline & & N52-Cu1-N42 & $95.52(15)$ \\
\hline & & N4-Cu1-N42 & $79.49(14)$ \\
\hline & & O72-Cu1-N42 & 172.42(15) \\
\hline & & $\mathrm{Cu} 1-\mathrm{O} 1-\mathrm{Fe} 1$ & $119.15(14)$ \\
\hline & & $\mathrm{C} 22-\mathrm{O} 20-\mathrm{Fe} 1$ & $135.9(3)$ \\
\hline & & C63-O61-Fe1 & $135.8(3)$ \\
\hline & & C63-O62-Cu1 & $133.0(3)$ \\
\hline & & C73-O71-Fe1 & 137.1(3) \\
\hline & & C73-O72-Cu1 & $132.7(3)$ \\
\hline
\end{tabular}

\section{Angles ( $\left.{ }^{\circ}\right)$}

$\mathrm{O} 20-\mathrm{Fe} 1-\mathrm{O} 71$

$7-\mathrm{Fe} 1-\mathrm{O} 1$ 
$\mathrm{Mn}^{\mathrm{III}} \mathrm{Mn}^{\mathrm{II}}$ [35], $\mathrm{Fe}^{\mathrm{III}} \mathrm{Fe}^{\mathrm{II}}$ [37], $\mathrm{Fe}^{\mathrm{III}} \mathrm{Zn}^{\mathrm{II}}$ [36], $\mathrm{Fe}^{\mathrm{III}} \mathrm{Mn}^{\mathrm{II}}$ [34] and $\mathrm{Fe}^{\mathrm{III}} \mathrm{Ni}^{\mathrm{II}}$ [33] complexes with the same ligand. The terminal $\mathrm{Fe}^{\mathrm{III}}-\mathrm{O}$ (phenolate) bond length [1.902(3) $\left.\AA\right]$ in $\mathbf{1}$ is almost identical to that in the FeMn PAP from sweet potato (1.88 $\AA$ ) [24], and is within the range of those found in the corresponding homobinuclear and heterobinuclear complexes, but is approximately $0.1 \AA$ shorter than the $\mathrm{Fe}^{\mathrm{III}}-\mathrm{O}_{\mathrm{tyr}}(2.05 \AA)$ in the native red kidney bean PAP enzyme [22]. Notably, in comparison with the bond lengths of the related model complexes and the known PAP structures, the $\mathrm{Cu}-\mathrm{N} 42$ [2.342(4) $\AA]$ and $\mathrm{Cu}-\mathrm{O} 72[2.300(4) \AA]$ bond lengths are elongated owing to the Jahn-Teller effect of the $\mathrm{Cu}^{\mathrm{II}}$ ion.

\section{Mass spectrometry}

Complex 1, dissolved $(2 \mathrm{mM})$ in an ethanol/water mixture (70:30\%) was subjected to ion spray ionization mass spectrometry (Fig. 2a). The isotope pattern (Fig. 2b) indicates that within the limits of instrument sensitivity, only fragments with heterobinuclear $\mathrm{FeCu}$ centers are present. An analysis of the fragment ion pattern reveals four main groups centered at mass-to-charge $(\mathrm{m} / \mathrm{z})$ ratios of $723,692,677$ and 661 (Fig. 2b). These peaks correspond to species where the ligand does not undergo fragmentation; $\mathrm{m} / \mathrm{z}$ species where the ligand was clearly fragmented are not further considered here. The four groups of peaks can only be accommodated if the ligand itself is deprotonated. The latter $(\mathrm{m} / \mathrm{z} \sim 661)$ corresponds to a fragment of the $\mathrm{Fe}^{\mathrm{II}} \mathrm{Cu}^{\mathrm{II}}$ complex without bridging ligands (note that the $\mathrm{Fe}$ is reduced: $\left.\left[\left(\mathrm{C}_{34} \mathrm{H}_{33} \mathrm{~N}_{5} \mathrm{O}_{2}\right) \mathrm{Fe}^{\mathrm{II}} \mathrm{Cu}^{\mathrm{II}}-\mathrm{H}\right]^{+}\right)$. The next group $(\mathrm{m} / z \sim 677)$ is best interpreted in terms of an $\mathrm{Fe}^{\mathrm{III}} \mathrm{Cu}^{\mathrm{II}}$ complex with one hydroxy ligand $\left\{\left[\left(\mathrm{C}_{34} \mathrm{H}_{33} \mathrm{~N}_{5} \mathrm{O}_{2}\right) \mathrm{Fe}^{\mathrm{III}} \mathrm{Cu}^{\mathrm{II}}(\mathrm{OH})-\mathrm{H}\right]^{+}\right\}$, while the fragment at $\mathrm{m} / \mathrm{z} \sim 692$ is likely to be due to a complex without any bridging ligands (i.e., no carboxylates or hydroxides) but with an associated methoxy group $\left\{\left[\left(\mathrm{C}_{34} \mathrm{H}_{33} \mathrm{~N}_{5} \mathrm{O}_{2}\right) \mathrm{Fe}^{\mathrm{III}} \mathrm{Cu}^{\text {II }}\left(\mathrm{CH}_{3} \mathrm{O}\right)-\mathrm{H}\right]^{+}\right\}$, which may arise from the fragmentation of the ethanol in the ion spray. The remaining fragment $(\mathrm{m} / \mathrm{z} \sim 723)$ corresponds to a complex containing both a hydroxide and an ethanol adduct $\left\{\left[\left(\mathrm{C}_{34} \mathrm{H}_{33} \mathrm{~N}_{5} \mathrm{O}_{2}\right) \mathrm{Fe}^{\text {III }} \mathrm{Cu}^{\mathrm{II}}\left(\mathrm{CH}_{3} \mathrm{CH}_{2} \mathrm{OH}\right)(\mathrm{OH})-\mathrm{H}\right]^{+}\right\}$. Interestingly Holman et al. [39] have X-ray crystallographic data for the dicarboxylate and monocarboxylate bridged $\left[\mathrm{Fe}^{\mathrm{III}} \mathrm{Cu}^{\mathrm{II}}(\mathrm{BPMP})(\mathrm{OAc})_{2}\right]\left(\mathrm{BPh}_{4}\right)$ and $\left[\mathrm{Fe}^{\mathrm{III}} \mathrm{Cu}^{\mathrm{II}}(\mathrm{BPMP})(\mathrm{OAc})(\mathrm{OMe})\right]\left(\mathrm{BPh}_{4}\right)$ species [where HBPMP is 6-bis[(bis(2pyridylmethyl)amino)methyl]-4-methylphenol], the latter having a methoxide coordinated to the $\mathrm{Fe}^{\mathrm{III}}$. The presence of homobinuclear species of equivalent composition would be characterized by peaks at $m / z$ 732, 667, 700 and 686 for $\mathrm{Cu}(\mathrm{II}) / \mathrm{Cu}(\mathrm{II})$ and $m / z$ 717, 652, 685 and 671 for $\mathrm{Fe}(\mathrm{III}) / \mathrm{Fe}$ (II) with quite different intensity patterns. Clearly the mass spectrum (Fig. 2a) shows that these peaks are not present and furthermore the characteristic isotope pattern for binuclear copper species is not observed for any of the peaks at lower $\mathrm{m} / \mathrm{z}$ values. Thus, mass spectrometry suggests that upon dissolving the $\mathrm{FeCu}$ complex in an ethanol/water mixture the bridging carboxylate groups are removed, and at least one water-based ligand is bound to the metal center. 

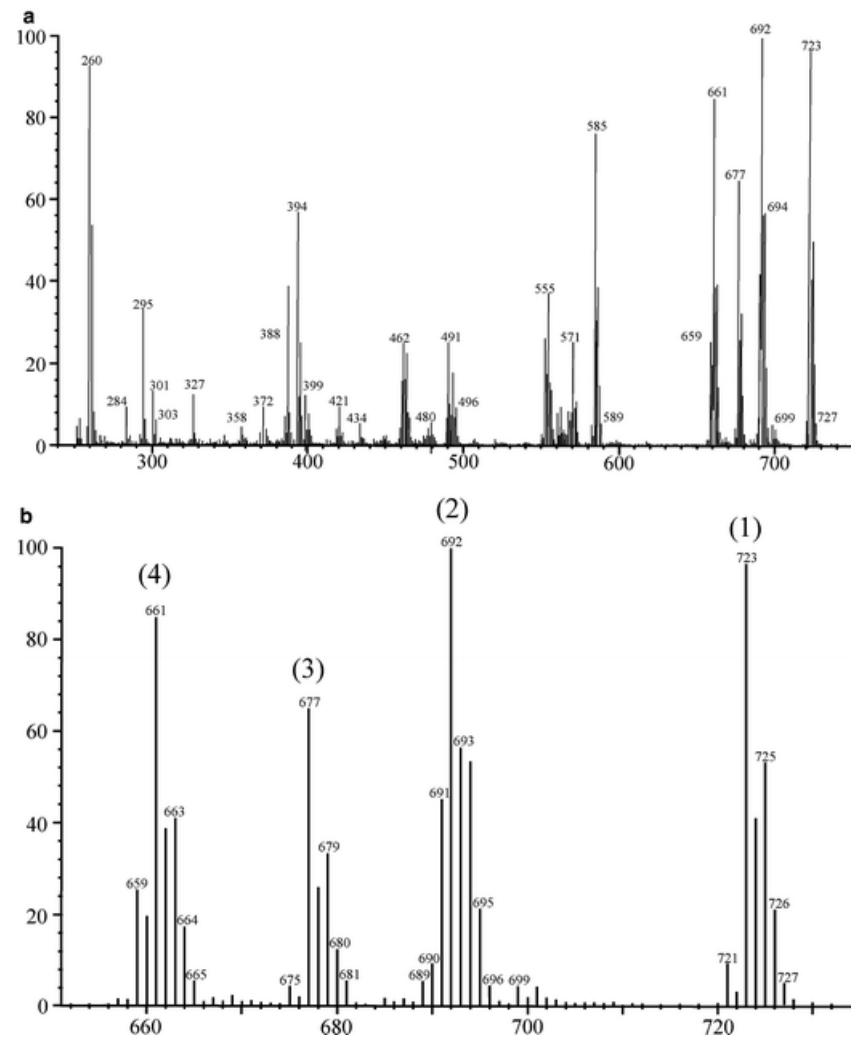

Fig. 2 a Ion spray ionization mass spectrum of $\mathbf{1}$ dissolved in a 70:30\% ethanol/water mixture and $\mathbf{b}$ expansion of the mass spectrum: $1 \mathrm{~m} / z \sim 723\left[\left(\mathrm{C}_{34} \mathrm{H}_{33} \mathrm{~N}_{5} \mathrm{O}_{2}\right) \mathrm{Fe}^{\mathrm{III}} \mathrm{Cu}^{\mathrm{II}}\left(\mathrm{CH}_{3} \mathrm{CH}_{2} \mathrm{OH}\right)(\mathrm{OH})-\mathrm{H}\right]^{+} ; 2 \mathrm{~m} / \mathrm{z}$ $\sim 692\left[\left(\mathrm{C}_{34} \mathrm{H}_{33} \mathrm{~N}_{5} \mathrm{O}_{2}\right) \mathrm{Fe}^{\mathrm{III}} \mathrm{Cu}^{\mathrm{II}}\left(\mathrm{CH}_{3} \mathrm{O}\right)-\mathrm{H}\right]^{+} ; 3 \mathrm{~m} / z \sim 677\left[\left(\mathrm{C}_{34} \mathrm{H}_{33} \mathrm{~N}_{5} \mathrm{O}_{2}\right) \mathrm{Fe}^{\mathrm{III}} \mathrm{Cu}^{\mathrm{II}}(\mathrm{OH})-\mathrm{H}\right]^{+} ; 4 \mathrm{~m} / z \sim 661$ $\left[\left(\mathrm{C}_{34} \mathrm{H}_{33} \mathrm{~N}_{5} \mathrm{O}_{2}\right) \mathrm{Fe}^{\mathrm{II}} \mathrm{Cu}^{\mathrm{II}}-\mathrm{H}\right]^{+}$. See text for details of peak assignments

\section{Potentiometric equilibrium determination}

Potentiometric titration of 1 in the ethanol/water mixture $(70: 30 ; \mathrm{I}=0.1 \mathrm{M} \mathrm{KCl})$ revealed $\mathrm{p} K_{\mathrm{a}}$ values of 5.25, 6.20 and 7.82 (Fig. 3). These values lie close to those determined for the corresponding isostructural $\mathrm{Fe}^{\mathrm{III}} \mathrm{Zn}^{\mathrm{II}}\left(\mathrm{p} K_{\mathrm{a} 1}=4.86, \mathrm{p} K_{\mathrm{a} 2}=6.00\right.$ and $\left.\mathrm{p} K_{\mathrm{a} 3}=7.22\right)$ and $\mathrm{Fe}^{\mathrm{III}} \mathrm{Ni}^{\mathrm{II}}$ $\left(\mathrm{p} K_{\mathrm{a} 1}=5.30, \mathrm{p} K_{\mathrm{a} 2}=6.80\right.$ and $\left.\mathrm{p} K_{\mathrm{a} 3}=8.61\right)$ complexes $[33,36]$. These protonation equilibria were previously interpreted in terms of the dissociation of the two bridging carboxylate groups (Fig. 1). The dissociation of one carboxylate leads to a species described as $\left(\mathrm{H}_{2} \mathrm{O}\right) \mathrm{Fe}-$ $\mu(\mathrm{OAc})-M\left(\mathrm{H}_{2} \mathrm{O}\right)(M$ is $\mathrm{Fe}, \mathrm{Cu}, \mathrm{Zn}, \mathrm{Ni}$ and $\mathrm{Mn})$, where $\mathrm{p} K_{\mathrm{a} 1}$ corresponds to the $\mathrm{Fe}^{\text {III }}$-bound aqua ligand. It has been proposed that upon the dissociation of the second carboxylate bridge a second water ligand is bound to $\mathrm{Fe}^{\mathrm{III}}$; upon its deprotonation a $\mu-\mathrm{OH}$ bridge is formed $\left(\mathrm{p} K_{\mathrm{a} 2}\right)$. Finally, $\mathrm{p} K_{\mathrm{a} 3}$ is ascribed to the deprotonation of the $\mathrm{Cu}-\mathrm{H}_{2} \mathrm{O}[33,34,36]$. The observed lability of the metal-carboxylate bonds in related complexes [57], and the need for a nucleophile to initiate catalysis are consistent with this proposal. However, from the $\mathrm{pH}$ dependence of its kinetics parameters (see later) it appears that $\mathbf{1}$ has only two protonation equilibria relevant to catalysis. 


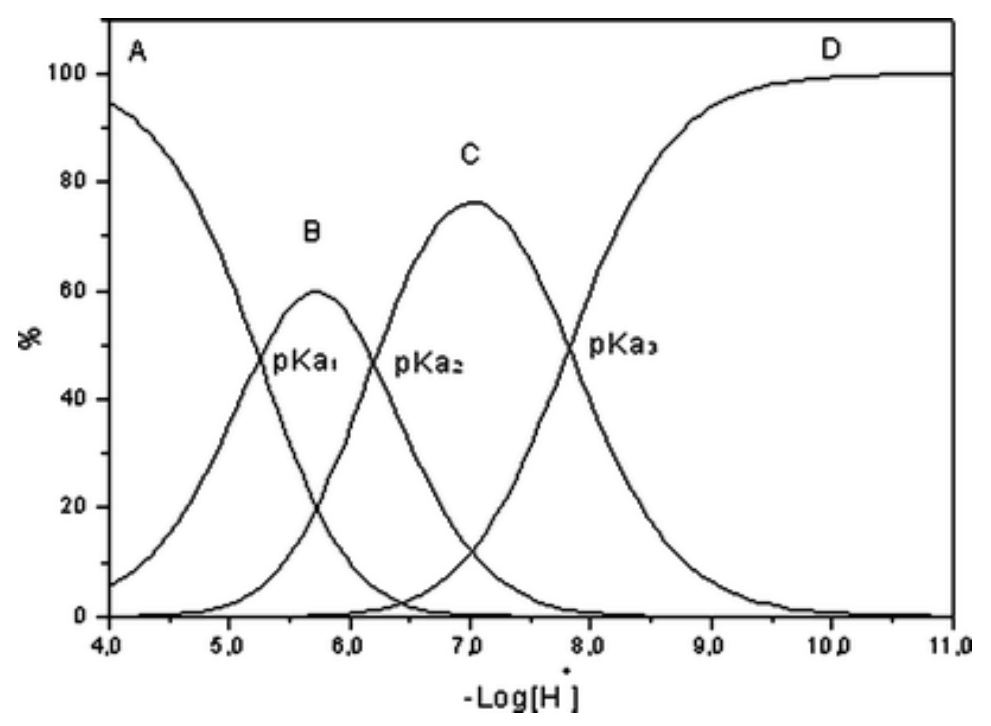

Fig. 3 Species distribution curves of 1 as a function of $\mathrm{pH}$. [ $\left.\mathrm{Fe}-\mu-(\mathrm{OAc})_{2}-\mathrm{Cu}\right] \cdot\left[\left(\mathrm{H}_{2} \mathrm{O}\right) \mathrm{Fe}-\mu(\mathrm{OAc})-\right.$ $\left.\mathrm{Cu}\left(\mathrm{H}_{2} \mathrm{O}\right)\right]$ (species $\left.A\right)$; $\left[\left(\mathrm{H}_{2} \mathrm{O}\right)_{n} \mathrm{Fe}-(\mathrm{OAc})-\mathrm{Cu}\left(\mathrm{H}_{2} \mathrm{O}\right)\right] \cdot\left[(\mathrm{HO})\left(\mathrm{H}_{2} \mathrm{O}\right) \mathrm{Fe}-(\mathrm{OAc})-\mathrm{Cu}\left(\mathrm{H}_{2} \mathrm{O}\right)\right]($ species $B)+\mathrm{H}^{+}$, $\mathrm{p} K_{\mathrm{al}}=5.25 ;\left[(\mathrm{OH})\left(\mathrm{H}_{2} \mathrm{O}\right) \mathrm{Fe}-(\mathrm{OAc})-\mathrm{Cu}\left(\mathrm{H}_{2} \mathrm{O}\right)\right] \cdot\left[(\mathrm{OH}) \mathrm{Fe}-(\mathrm{OH})-\mathrm{Cu}\left(\mathrm{H}_{2} \mathrm{O}\right)\right]($ species $C)+\mathrm{OAc}^{-}+\mathrm{H}^{+}$, $\mathrm{p} K_{\mathrm{a} 2}=6.20 ;\left[(\mathrm{OH}) \mathrm{Fe}-(\mathrm{OH})-\mathrm{Cu}\left(\mathrm{H}_{2} \mathrm{O}\right)\right] \cdot[(\mathrm{OH}) \mathrm{Fe}-(\mathrm{OH})-\mathrm{Cu}(\mathrm{HO})]($ species $D)+\mathrm{H}^{+}, \mathrm{p} K_{\mathrm{a} 3}=7.82$. See text for details

\section{Electrochemistry}

Electrochemical studies (square-wave voltammetry) of 1 in $\mathrm{MeCN}\left(0.1 \mathrm{Mn}-\mathrm{Bu}_{4} \mathrm{NPF}_{6}\right.$ as supporting electrolyte) reveal two quasireversible redox processes (versus ferrocenium/ferrocene) as shown in Fig. $4 ; \mathrm{E}_{1 / 2}=-1.0$ and $-1.3 \mathrm{~V}$ (relative to the ferrocenium/ferrocene couple) are attributed to the $\mathrm{Fe}^{\mathrm{III}}+\mathrm{e}^{-} \rightarrow \mathrm{Fe}^{\mathrm{II}}$ and $\mathrm{Cu}^{\mathrm{II}}+\mathrm{e}^{-} \rightarrow \mathrm{Cu}^{\mathrm{I}}$ couples, respectively. The value for the $\mathrm{Fe}^{\mathrm{III}} / \mathrm{Fe}^{\mathrm{II}}$ couple is in close agreement with those observed for the FeNi $(-0.94 \mathrm{~V})$ [33], FeMn $(-0.87 \mathrm{~V})$ [34], FeZn (-0.91 V) [36] and FeFe (-0.89 V) [38] complexes, implying that the coordination environment around the $\mathrm{Fe}^{\mathrm{III}}$ ion is similar in these $\mathrm{Fe}^{\mathrm{III}} \mathrm{M}^{\mathrm{II}}-\mathrm{BPBPMP}$ complexes.

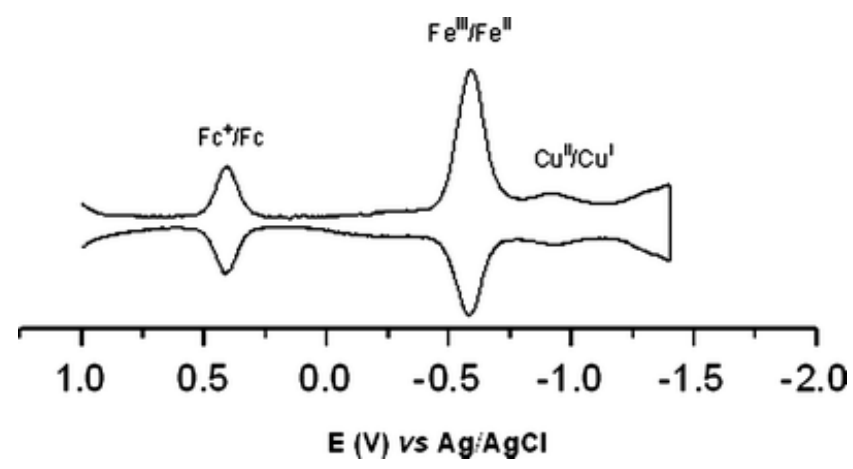

Fig. 4 Square-wave voltammogram of 1 in $\mathrm{CH}_{3} \mathrm{CN}$ with $0.1 \mathrm{M} \mathrm{n}-\mathrm{Bu}_{4} \mathrm{NPF}_{6}$ at $100 \mathrm{mV} \mathrm{s}{ }^{-1}$ scan rate. Ferrocene was used as an internal standard.

\section{Electronic absorption spectroscopy}

The electronic spectrum of 1 in MeCN has a broad band at $546 \mathrm{~nm}\left(\varepsilon=3,400 \mathrm{M}^{-1} \mathrm{~cm}^{-1}\right)$, which can be attributed to the terminal phenolate-to-Fe ${ }^{\mathrm{III}}$ charge-transfer transition [33-38]. A shoulder at $330 \mathrm{~nm}$ is also observed, which most probably arises from a second phenolate-to$\mathrm{Fe}^{\mathrm{III}}$ charge-transfer transition. The modified $\mathrm{Fe}^{\mathrm{III}} \mathrm{Cu}^{\mathrm{II}} \mathrm{PAP}$ from porcine uterus shows a tyrosine-to-Fe ${ }^{\mathrm{III}}$ charge-transfer transition at $545 \mathrm{~nm}\left(\varepsilon=3,400 \mathrm{M}^{-1} \mathrm{~cm}^{-1}\right)$ [25], and thus 1 can be considered as a good synthetic analogue for the chromophoric site of the enzyme. In aqueous solutions ( $\mathrm{pH}$ 6.0) the charge-transfer transition is shifted towards higher energy 
( $\lambda=504 \mathrm{~nm} ; \varepsilon=2,500 \mathrm{M}^{-1} \mathrm{~cm}^{-1}$ ). This observation is interpreted in terms of a different coordination environment in the two solvents. In $\mathrm{MeCN}$ the carboxylates remain bound to the metal ions forming an $\left[\mathrm{Fe}^{\mathrm{III}}-(\mu)(\mathrm{OAc})_{2}-\mathrm{Cu}^{\mathrm{II}}\right]$ complex. Upon dissolving 1 in an aqueous solution the two bridging carboxylate groups are removed and are likely to be replaced by two water molecules to form an $\left[\mathrm{Fe}^{\mathrm{III}}-(\mu) \mathrm{OH}-\mathrm{Cu}^{\mathrm{II}} \mathrm{OH}_{2}\right]$ complex (vide supra). It is probable that the increased charge donation from the hydroxide ligand reduces the Lewis acidity of the ferric center by increasing the energy of the $\mathrm{T}_{2 g}$ orbitals.

\section{X-ray absorption spectroscopy}

X-ray absorption spectra collected for $\mathbf{1}$ in both the solid (transmission and fluorescence modes) and the dissolved state (solvent, ethanol/water 70:30\%) are shown in Fig. 5. The preedge features magnified in the insets are due to $1 s \rightarrow 3 d$ transitions in both $\mathrm{Fe}$ (Fig. 5a) and $\mathrm{Cu}$ (Fig. 5b). The edge positions are 7,124.5 and 8,987.9 eV for $\mathrm{Fe}$ and $\mathrm{Cu}$, respectively. Neither the K-edge nor the pre-edge peaks changed position with the different samples, indicating that the $\mathrm{Fe}$ and $\mathrm{Cu}$ remain in the +3 and +2 oxidation states, respectively. Significantly, there was no indication of photoreduction of the $\mathrm{Fe}^{\mathrm{III}}$ by comparing the first and last scans. For the samples in solution, spectra were collected over a period of $36 \mathrm{~h}$ without showing signs of photoreduction. Fitting of the pre-edge region gave peak positions of 7,114.2 and 8,977.4 eV for $\mathrm{Fe}$ and $\mathrm{Cu}$, respectively, and these did not vary $( \pm 0.5 \mathrm{eV})$ between the solid and solution samples. Again, this is consistent with a stable $\mathrm{Fe}^{\mathrm{III}}$ oxidation state in solution as the $1 s \rightarrow 3 d$ transitions in $\mathrm{Fe}^{\mathrm{II}}$ are shifted approximately $1.5 \mathrm{eV}$ to lower energy [58]. The ${ }^{5} \mathrm{~T}_{2 g}-{ }^{5} \mathrm{E}_{g}$ splitting of the Fe pre-edge peak due to the $d^{6}$ configuration of the final state was not observed. The area of the pre-edge peaks using normalized spectra were $0.077,0.104$ and $0.305 \mathrm{eV}$ for the Fe solid transmission detected, the solid fluorescence detected and the solution fluorescence detected samples, respectively. For the $\mathrm{Cu}$ pre-edge the respective areas are $0.09,0.12$ and $0.09 \mathrm{eV}$. The areas of the $\mathrm{Cu}$ peaks do not show significant variation, while there is a significant difference in the area of the Fe solid and solution pre-edge peaks. A study of a series of six-coordinate, five-coordinate and four-coordinate iron complexes [59] has shown that the areas of these peaks typically fall in the range $0.06-0.095,0.12-0.19$ and $0.23-0.25 \mathrm{eV}$, respectively. While the pre-edge peak area of the solid sample of $\mathbf{1}$ is within the range expected for a six-coordinate $\mathrm{Fe}$, the peak area of the solution sample is not.

It is well known that the intensity of these $1 s \rightarrow 3 d$ transitions is electric-dipoleforbidden for centrosymmetric systems and gains intensity from either the weak electric quadrupole mechanism or by departures from strict centrosymmetric symmetry. Lowering the symmetry allows electric dipole intensity from $3 d-4 p$ mixing, and thus the intensity of the $1 s \rightarrow 3 d$ transitions is a probe for $\mathrm{Fe}^{\mathrm{III}}$ coordination. However, since the degree of $3 d-4 p$ mixing is dependent on the geometry as well as the coordination of the molecule [58], the relationship between four-coordination, five-coordination, six-coordination and the intensity of the $1 s \rightarrow 3 d$ transitions breaks down when the system has a large distortion. Thus, while our data may be interpreted in terms of $\mathrm{Fe}^{\mathrm{III}}$ changing from six-coordinate to five-coordinate or four-coordinate on going from the solid state to an ethanolic solution (see previous paragraph), at present a significantly more distorted environment in solution compared with that in the solid state cannot be ruled out.

Figures 6 and 7 show the EXAFS spectra in k- and R-space, respectively, for the three types of samples extracted from Fig. 5. The $\mathrm{Cu}$ site does not appear to be affected by the change from the solid state to solution (Fig. 6a), implying that the number and the identity of the directly coordinating atoms do not change. In contrast, the Fe K-edge data collected for the complex dissolved in solution differed markedly from the data of the solid state (Fig. 6b). Modeling the Fe EXAFS data using different windows in R-space implies that the change is in the first coordination sphere, leading to a lower coordination number than 6 upon dissolution, consistent with the analysis of the pre-edge features (vide supra). Several model descriptions of the $\mathrm{Fe}$ and $\mathrm{Cu}$ scatterers of $\mathbf{1}$ can be adequately refined to reproduce the observed spectra (Table S1), but these models require a large number of parameters owing to the low symmetry of $\mathbf{1}$ and can therefore not be meaningfully interpreted without applying 
additional constraints. Owing to the low symmetry of 1 several model descriptions of the Fe and $\mathrm{Cu}$ scatterers can be adequately refined to reproduce the observed spectra. However, the differences observed in the Fe spectrum measured in the solid state and in solution imply a structural change, which is consistent with a change in the coordination number from 6 to a smaller number (vide supra).
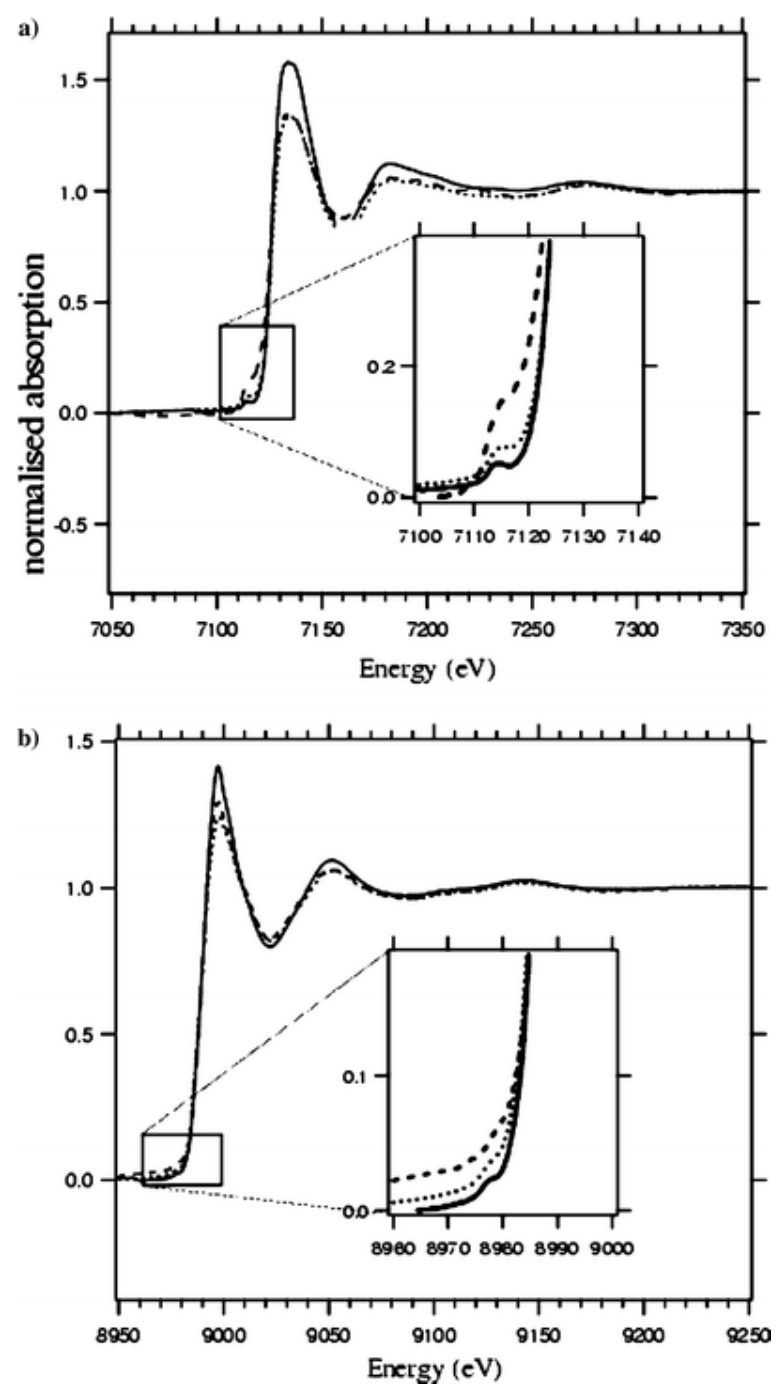

Fig. 5 The K-edge X-ray absorption spectroscopy spectra for $\mathrm{Fe}(\mathbf{a})$ and $\mathrm{Cu}(\mathbf{b})$ measured at $10 \mathrm{~K}$. The spectra are for diluted powder samples measured using transmission (solid lines) and fluorescence (dotted lines) detection. The dashed spectra is for a frozen solution (ethanol/water 70:30\%) using fluorescence detection. The insets show the weak $1 s \rightarrow 3 d$ pre-edge features (see text). 

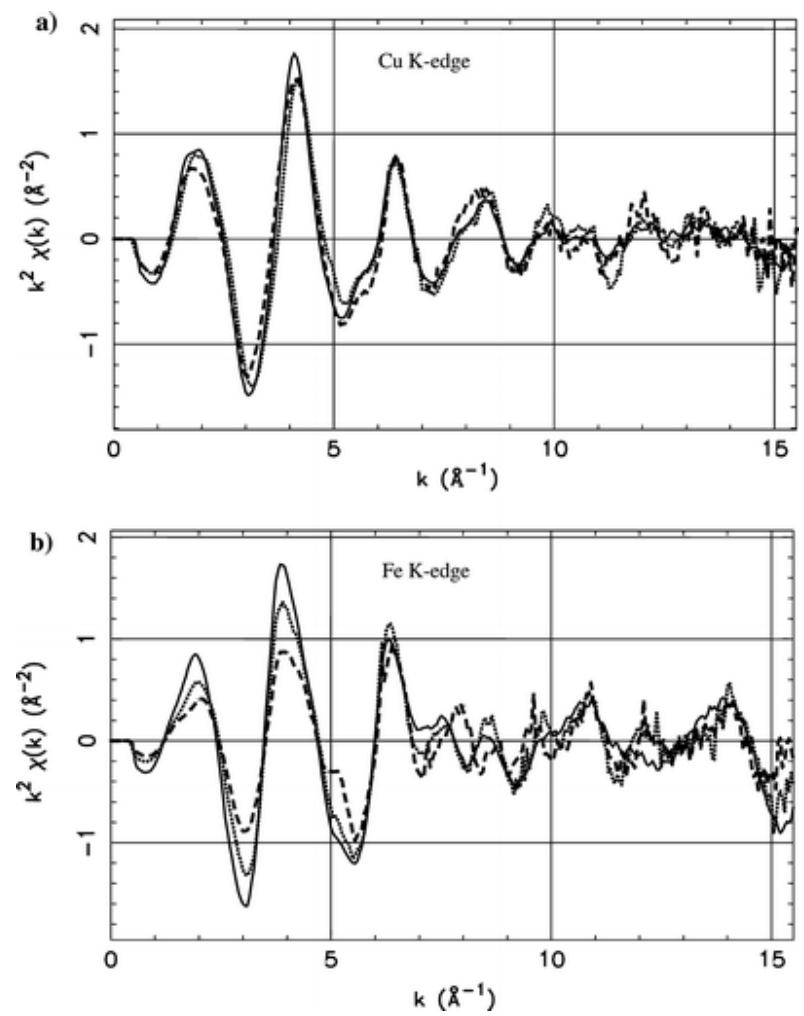

Fig. 6 K-edge extended X-ray absorption fine structure (EXAFS) spectra of $\mathrm{Fe}(\mathbf{a})$ and $\mathrm{Cu}(\mathbf{b})$ at $10 \mathrm{~K}$. The spectra were acquired in the solid state using transmission (solid lines) and fluorescence detection (dotted lines) and in a frozen solution (ethanol/water 70:30\%) using fluorescence detection (dashed lines).
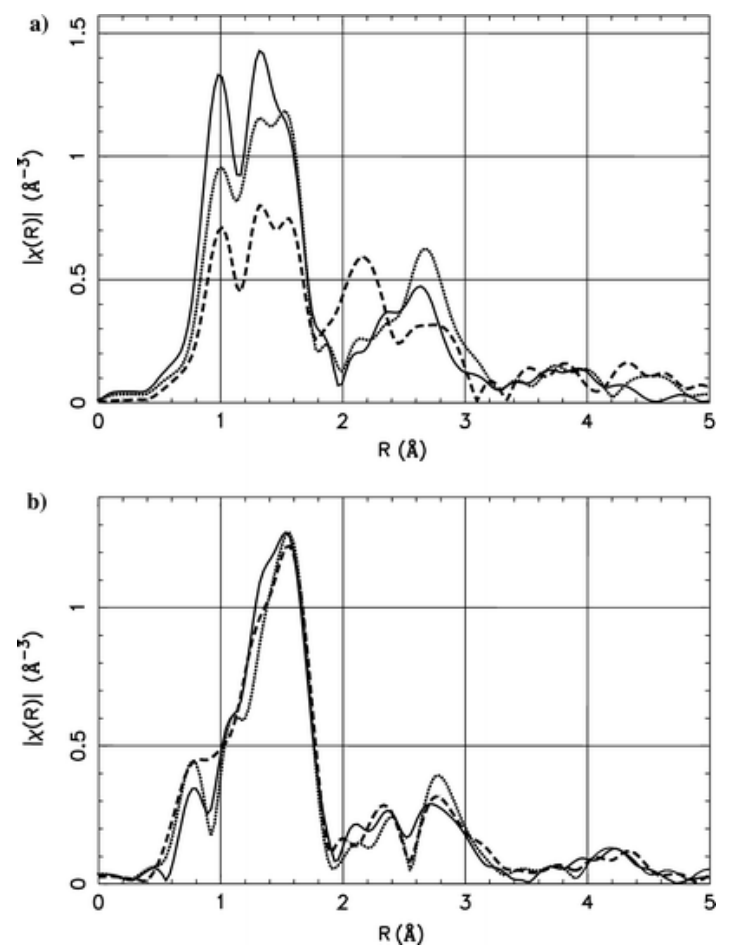

Fig. 7 The magnitude of the Fourier transform into R-space for the $\mathrm{Fe}(\mathbf{a})$ and $\mathrm{Cu}(\mathbf{b})$ EXAFS spectra shown in Fig.5. See caption to Fig.6 for the different curves. A weighting factor of $k_{\mathrm{w}}=2$ was used with a Kaiser-Bessel window in the $k$-range of [2:14], $d k=3$ for $\mathrm{Fe}(\mathbf{a})$ and of $\mathrm{k}=[2: 15], \mathrm{dk}=3$ for $\mathrm{Cu}(\mathbf{b})$. 
Improvements to the current model may be greatly assisted both by comparison to related $\mathrm{Fe}^{\mathrm{III}} \mathrm{M}^{\mathrm{II}}$ systems [33-38] and in using constraints based on treating the 2,4-BDNPP ligand with molecular mechanics while simultaneously fitting the EXAFS data. The rationale is that, although this low-symmetry system is complicated and multiple scattering is important, the 2,4-BDNPP ligand is expected to keep its structural integrity while remaining conformationally flexible. While the aromatic fragments are rigid, the torsional angles within the 2,4-BDNPP ligand are less rigid and will accommodate different metal-ligand bond lengths. This system is thus far more constrained than one would at first expect and together with the previously described approach may prove ideal for studying the EXAFS spectra of bimetallic systems.

\section{Electron paramagnetic resonance}

In contrast to the EPR spectra for $\left[\mathrm{Fe}^{\mathrm{III}} \mathrm{Cu}^{\mathrm{II}}(\mathrm{BPMP}) \mathrm{Cl}_{2}(\mathrm{HOMe})\right]^{2+}[60]$, $\left[\mathrm{Fe}^{\mathrm{III}} \mathrm{Cu}^{\mathrm{II}}(\mathrm{BPMP})(\mathrm{OAc})_{2}\right]\left(\mathrm{BPh}_{4}\right)[39]$ and $\left[\mathrm{Fe}^{\mathrm{III}} \mathrm{Cu}^{\mathrm{II}}(\mathrm{BPMP})(\mathrm{OAc})(\mathrm{OMe})\right]\left(\mathrm{BPh}_{4}\right)$ [39], which are relatively simple (resonances at $\mathrm{g}_{\text {eff }}$ of 12.0, 8.3 and 12.0, 8.3, respectively), and, in conjunction with Mössbauer spectroscopy and/or magnetic susceptibility, interpreted in the strong-exchange regime $(|J|>|D|)$, the X-band EPR spectrum of 1 (Fig. 8a) dissolved in ethanol/water (70:30\%) reveals a complex pattern of resonances over a large field range. At first glance, there are spectral features which may possibly be attributed to the presence of mononuclear $\mathrm{Fe}^{\mathrm{III}}, \mathrm{Cu}^{\mathrm{II}}$ and binuclear dipole-dipole coupled $\mathrm{Cu}_{2}{ }^{\mathrm{II}}$ centers. However, on the basis of reasons outlined in the following and computer simulation studies the spectral features in Fig. 8a arise from the intact heterobinuclear complex. 

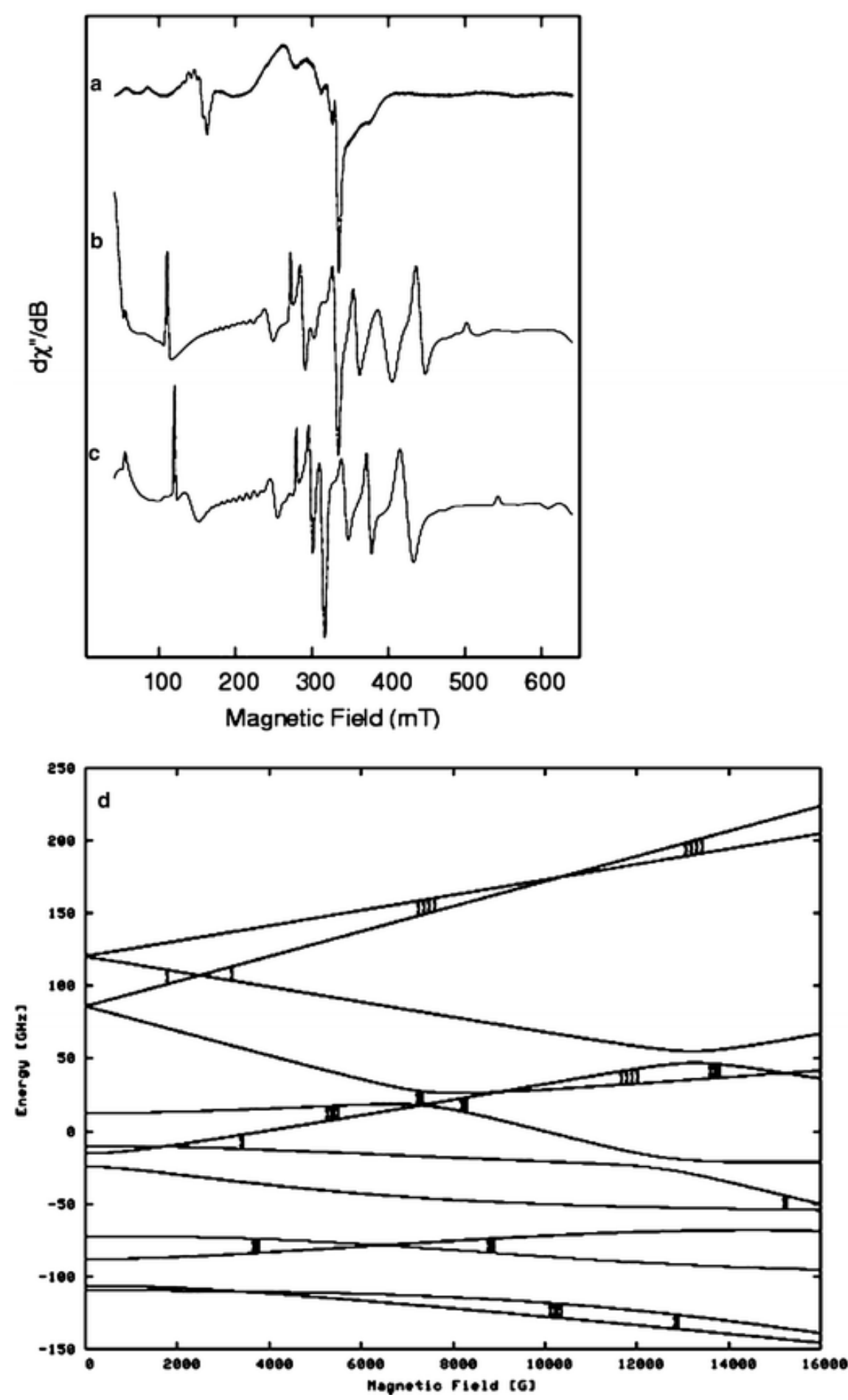

Fig. 8 X-band EPR spectra of the heterobinuclear $\mathrm{Fe}^{\mathrm{III}} \mathrm{Cu}^{\mathrm{II}}$ complex 1. a Experimental spectrum of 1 $(2 \mathrm{mM})$ dissolved in ethanol/water $(70 / 30 \%)$ and recorded at $6.3 \mathrm{~K}, v=9.35551 \mathrm{GHz}$ with a microwave power of $20 \mathrm{~mW}$, a modulation amplitude of $0.1 \mathrm{mT}$ and a receiver gain of $47 \mathrm{~dB}$. b Computer simulation of a with the following spin Hamiltonian parameters: $\mathrm{Fe}^{\mathrm{III}} g=2, D=1 \mathrm{~cm}^{-1}$,

$E / D=0.2 ; \mathrm{Cu}^{\mathrm{II}} g=2.40, g \perp=2.12, A=0.002 \mathrm{~cm}^{-1}, \mathrm{~A} \perp=0.0132 \mathrm{~cm}^{-1} ; \mathrm{Fe}^{\mathrm{III}}-\mathrm{Cu}^{\mathrm{II}} \chi=90^{\circ}, \stackrel{\varrho}{\ell}=20^{\circ}, r=3.2 \AA$, $J=0.5 \mathrm{~cm}^{-1}$. c Computer simulation using the same spin Hamiltonian parameters as for $\mathbf{b}$ except $D=1.2 \mathrm{~cm}^{-1}$. $\mathbf{d}$ Energy level diagram for the simulation given in $\mathbf{b}$ with the magnetic field applied along the $z$ principal axis. See supplementary material (Fig. S1) for the energy level diagrams with the magnetic field applied along the $x$ and $y$ directions. 
The EPR spectrum (Fig. 8a) can be divided into three regions of interest, 50-110, 110-180 and 180-400 $\mathrm{mT}$. The intense resonances at low field (50-110 $\mathrm{mT})$ are observed at temperatures up to $100 \mathrm{~K}$, indicating that the paramagnetic species has relatively long spin lattice relaxation times, which is inconsistent with the species being a rhombically distorted, magnetically isolated high-spin $\mathrm{Fe}^{\mathrm{III}}$ center. In addition, a strong resonance at $g_{\text {eff }}=4.3$ is not observed as would be expected for a rhombically distorted $(E / D=0.3)$ high-spin $\mathrm{Fe}^{\mathrm{III}}$ center. Consequently, the observed resonances at low field are likely to arise from a coupled $\mathrm{Fe}^{\text {III- }}$ $\mathrm{Cu}^{\text {II }}$ spin system.

The resonances centered at $g_{\text {eff }} \sim 4(110-180 \mathrm{mT})$ resemble those commonly observed for formally forbidden half-field transitions $\left(\Delta M_{\mathrm{s}}= \pm 2\right)$ in binuclear $\mathrm{Cu}^{\mathrm{II}}$ complexes [61]. However, the mass spectrometry does not indicate the presence of any binuclear copper centers (Fig. 2). In addition, these resonances are far too intense in relation to the allowed $\left(\Delta M_{s}= \pm 1\right.$ ) transitions centered around $g_{\text {eff }} \sim 2$ for a binuclear $\mathrm{Cu}^{\mathrm{II}}$ complex and, second, the experimental conditions (with respect to receiver gain, modulation amplitude and microwave power) used to measure the spectrum (Fig. 8, legend) are not as extreme as usually required to measure formally forbidden $\Delta M_{s}= \pm 2$ transitions from binuclear $\mathrm{Cu}^{\mathrm{II}}$ complexes. Also the spacing (30.5 mT) of the resonances in the third region (180-400 mT) (Fig. 8a) is far too large for them to correspond to copper hyperfine coupling from either mononuclear or binuclear $\mathrm{Cu}^{\mathrm{II}}$ complexes. Consequently, these half-field resonances must also arise from a coupled $\mathrm{Fe}^{\mathrm{III}}-\mathrm{Cu}^{\mathrm{II}}$ center.

The resonances in the third region $(180-400 \mathrm{mT})$ are similar to those found for a dipole-dipole coupled imidazolate-bridged, binuclear $\mathrm{Fe}^{\mathrm{III}}-\mathrm{Cu}^{\mathrm{II}}$ porphyrin complex in which the $\mathrm{Fe}^{\mathrm{III}}$ ion exists in equilibrium between high and low spin [62]. Dipole-dipole coupling of the low-spin $\mathrm{Fe}^{\mathrm{III}}-\mathrm{Cu}^{\mathrm{II}}$ porphyrin complex produces an $\mathrm{S}=1\left(\mid M_{s}>, M_{\mathrm{s}}=1,0,-1\right)$ spin system giving rise to the observed transitions in this region. It is unlikely that such a spin equilibrium would exist for the $\left[\mathrm{Fe}^{\mathrm{III}} \mathrm{Cu}^{\mathrm{II}}(\mathrm{BPBPMP})(\mathrm{OAc})_{2}\right] \mathrm{ClO}_{4}$ complex dissolved in ethanol/water (70:30\%). Consequently, exchange coupling of high-spin $\mathrm{Fe}^{\mathrm{III}}(S=5 / 2)$ and $\mathrm{Cu}^{\mathrm{II}}(S=1 / 2)$ ions produces the spin states $S=2$ and 3, separated in energy by $3 \mathrm{~J}\left(\mathrm{H}=\mathrm{J} S_{1} \cdot S_{2}\right)$, with the $S=3$ spin state lowest for a ferromagnetically coupled center. A variable-temperature (6-130 K) EPR study (results not shown) of this complex in ethanol/water (70:30\%) suggests that the exchange coupling constant is small $\left(|J|<3 \mathrm{~cm}^{-1}\right)$, consistent with a $\mu$-OH bridge between the $\mathrm{Fe}^{\mathrm{III}}$ and $\mathrm{Cu}^{\mathrm{II}}$ centers.

Computer simulation (XSophe) of the EPR spectrum from the heterobinuclear $\mathrm{Fe}^{\mathrm{III}} \mathrm{Cu}^{\mathrm{II}}$ complex 1 employed the spin Hamiltonian (Eq. 1), in conjunction with matrix diagonalization and the mosaic misorientation linewidth model [53].

\section{$H=g_{\mathrm{Fq}} \beta B \quad S_{\mathrm{Fq}}+S_{\mathrm{Fq}} \quad D_{\mathrm{Fq}} \cdot S_{\mathrm{Fq}}-\beta B \cdot g_{\mathrm{Cu}} \cdot S_{\mathrm{Cu}}+S_{\mathrm{Cu}} \cdot A_{\mathrm{Cu}} \cdot I_{\mathrm{Cu}}+S_{\mathrm{Fq}} \cdot J_{\mathrm{Fq}} \cdot S_{\mathrm{Fq}}$}

Importantly, the linewidth models employed in the XSophe software [53] are inappropriate for this system and thus no attempt was made to reproduce the linewidths. Typically, on a PC with an AMD XP2100 processor the computational times were approximately $13 \mathrm{~h}$. In order to reproduce the spectral features observed in Fig. 8a it was necessary to use very small negative values of $J$ and positive values of the axial zero field splitting, indicative of the intermediate-exchange regime which results in significant state mixing. This is illustrated in the energy level diagrams (Figs. 8d, S1a, S1b) for the simulation shown in Fig. 8b, with the magnetic field (B) placed along the $z, x$ and $y$ principal directions, respectively. Two examples of simulated spectra are shown in Fig. 8b, c, whose spin Hamiltonian parameters are as follows: $\mathrm{Fe}^{\mathrm{III}} g=2, D=1 \mathrm{~cm}^{-1}, E / D=0.2 ; \mathrm{Cu}^{\mathrm{II}} g=2.40, g \perp$ $=2.12, A=0.002 \mathrm{~cm}^{-1}, A \perp=0.0132 \mathrm{~cm}^{-1}$; and $\mathrm{Fe}^{\mathrm{III}}-\mathrm{Cu}^{\mathrm{II}} \chi=90^{\circ},{ }^{\underline{Q}}=20^{\circ}, r=3.2 \AA, J=-0.5 \mathrm{~cm}^{-1}$ (Fig. 8b); $\mathrm{Fe}^{\mathrm{III}} g=2, \mathrm{D}=1.2 \mathrm{~cm}^{-1}, E / D=0.2 ; \mathrm{Cu}^{\mathrm{II}} g=2.40, g \perp=2.12, A=0.002 \mathrm{~cm}^{-1}, A \perp$ $=0.0132 \mathrm{~cm}^{-1}$; and $\mathrm{Fe}^{\mathrm{III}}-\mathrm{Cu}^{\mathrm{II}} \chi=90^{\circ}, \stackrel{\varrho}{=}=20^{\circ}, r=3.2 \AA, J=-0.5 \mathrm{~cm}^{-1}$ (Fig. 8c), respectively. The 
appearance of resonances around $g_{\text {eff }} 4$ (Fig. $8 \mathrm{c}$ ) is very sensitive to the choice of the spin Hamiltonian parameters, where the only difference between Fig. $8 \mathrm{~b}$ and $\mathrm{c}$ is an increase of $D$ by $0.2 \mathrm{~cm}^{-1}$. Splitting of this resonance has also been observed with certain choices of spin Hamiltonian parameters but the other spectral features have not been reproduced. Whilst the simulations are not perfect they do indicate that all of the spectral features can be interpreted in terms of a weakly ferromagentically coupled heterobinuclear $\mathrm{Fe}^{\mathrm{III}} \mathrm{Cu}^{\mathrm{II}}$ complex, and that the complexity of the spectrum can be attributed to a spin system in the intermediate-exchange regime $(|J| \sim|D|)$. The loss of the carboxylate bridging ligands is entirely consistent with these results and the spin Hamiltonian parameters for the $\left[\mathrm{Fe}^{\mathrm{III}} \mathrm{Cu}^{\mathrm{II}}(\mathrm{BPMP}) \mathrm{Cl}_{2}(\mathrm{HOMe})\right]^{2+}\left(\mathrm{J} \sim-3 \mathrm{~cm}^{-}\right.$ $\left.{ }^{1}\right)$ [60], [ $\left.\mathrm{Fe}^{\mathrm{III}} \mathrm{Cu}^{\mathrm{II}}(\mathrm{BPMP})(\mathrm{OAc})_{2}\right]\left(\mathrm{BPh}_{4}\right)\left(J=50 \mathrm{~cm}^{-1}\right)$ [39] and

$\left[\mathrm{Fe}^{\mathrm{III}} \mathrm{Cu}^{\mathrm{II}}(\mathrm{BPMP})(\mathrm{OAc})(\mathrm{OMe})\right]\left(\mathrm{BPh}_{4}\right)\left(J=-3 \mathrm{~cm}^{-1}\right)$ [39] complexes. A complete understanding of the spectrum (Fig. 8a) and the determination of a unique set of spin Hamiltonian parameters will require parallel-mode and/or high-field EPR experiments in conjunction with computer simulation studies, which are under way.

\section{Kinetics of hydrolysis and DNA cleavage}

Kinetics experiments to examine the phosphatase-like activity have been carried out under conditions of excess substrate (using the activated substrate 2,4-BDNPP [63]) as described elsewhere $[33,34,36]$. The $\mathrm{pH}$-dependence of the catalytic activity between 3.63 and 10.00 shows a bell-shaped profile (Fig. 9) with an optimum at about $\mathrm{pH}$ 7.0. Sigmoidal fits of the curve reveal $\mathrm{p} K_{\mathrm{a}}$ values of 5.2 and 8.5, which are in good agreement with the values of $\mathrm{pK}_{\mathrm{a} 1}$ and $\mathrm{p} K_{\mathrm{a} 3}$ obtained from potentiometric titration (vide supra). These results imply that the active species of $\mathbf{1}$ is of the type [ $\mathrm{Fe}^{\mathrm{III}}-(\mu) \mathrm{OH}-\mathrm{Cu}^{\mathrm{II}} \mathrm{OH}_{2}$ ]. In accordance with studies carried out with animal PAPs $[5,25,29,64]$, the first step in the hydrolytic mechanism is likely to involve the binding of the substrate to the divalent metal site, displacing a water molecule in the process. Thus, the decrease in reactivity at high $\mathrm{pH}$ is ascribed to the deprotonation of the $\mathrm{Cu}^{\text {II }}$-bound water molecule ( $\mathrm{p} K_{\mathrm{a}}=8.5$ ), which reduces the leaving tendency of the hydroxyl ion from $\mathrm{Cu}^{\text {II }}$. This $\mathrm{Cu}-\mathrm{H}_{2} \mathrm{O}$ bond is rather labile and may be removed during the ionization process in the mass spectrometer, resulting in a species with only one water ligand (vide supra). The other protonation equilibrium $\left(\mathrm{p} K_{\mathrm{a}}=5.2\right)$ is assigned to the deprotonation of an $\mathrm{Fe}^{\mathrm{III}}$-bound water molecule. Both a terminally bound and a bridging ligand are possible candidates. The former is in agreement with studies on pig PAP and the isostructural $\mathrm{Fe}^{\mathrm{III}} \mathrm{Zn}^{\mathrm{II}}$ and $\mathrm{Fe}^{\mathrm{III}} \mathrm{Mn}^{\mathrm{II}}$ complexes, which invoke a hydroxide terminally bound to $\mathrm{Fe}^{\mathrm{III}}$ as a nucleophile $[25,34,36,64]$. In contrast, the observation by EXAFS that upon dissolving $\mathbf{1}$ in ethanol/water (70:30\%) the coordination number of Fe changes from 6 to 5 supports the assignment of the bridging water molecule to $\mathrm{p} K_{\mathrm{a} 1}$. Interestingly, a recent report by Smoukov et al. [65], using electron-nuclear double resonance spectroscopy on pig PAP, suggests that in the resting state the $\mathrm{Fe}^{\mathrm{III}}$ site is also five-coordinate; no evidence for a terminally bound water ligand has been detected. It was thus proposed that the $\mu-\mathrm{OH}$ group acts as a nucleophile. This model is in line with the mechanism discussed for the $\mathrm{Mn}^{\mathrm{II}}$-dependent PAP from sweet potato $[24,30]$. The crystal structure of this enzyme in the presence of phosphate reveals an unusual coordination of the phosphate anion with three of its oxygen atoms coordinating to the two metal ions in the active site [24]. The bridging solvent molecule present in the resting enzyme is absent in the phosphate-bound form, consistent with its role as a nucleophile. 


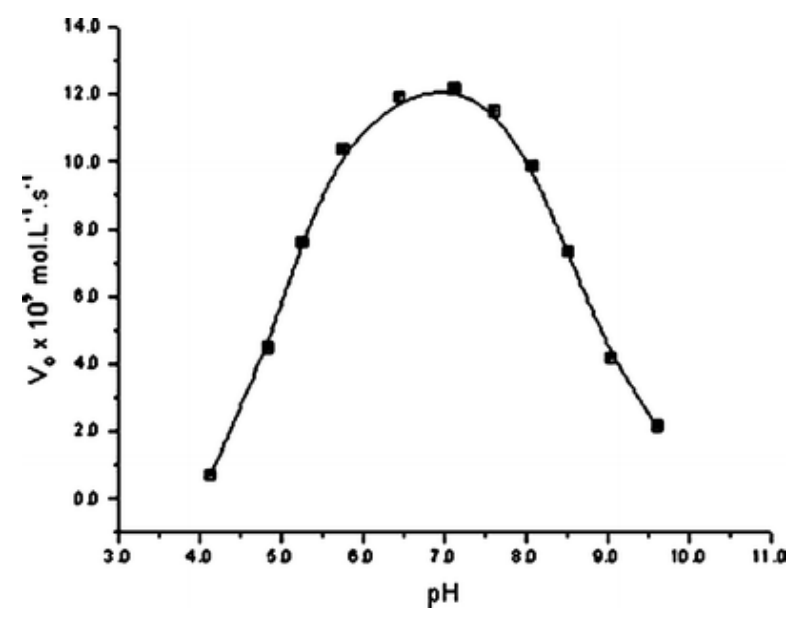

Fig. 9 Dependence of the reaction rate on the $\mathrm{pH}$ under the following conditions: water/acetonitrile $50 \%$ solution, $[1]=4.0 \times 10^{-5} \mathrm{~mol} \mathrm{l}^{-1},[2,4$-bis(dinitrophenol)phosphate $]=2.0 \times 10^{-3} \mathrm{M}$, [buffer $]=5.0 \times 10^{-}$ ${ }^{2} \mathrm{M}$ [buffer is 2-morpholinoethanesulfonic acid (MES), $N$-(2-hydroxyethyl)piperazine- $N^{\prime}$ ethanesulfonic acid and $N$-cyclohexyl-2-aminoethanesulfonic acid, $\left.I=0.1 \mathrm{M}\left(\mathrm{LiClO}_{4}\right)\right]$

The dependence of the initial rate on the concentration of 2,4-BDNPP at pH 6.8 displays Michaelis-Menten-type behavior. The Lineweaver-Burk linearization of these data (Fig. 10) gives the following kinetics parameters: $K_{\mathrm{m}}=1.1 \times 10^{-2} \mathrm{M}, V_{\max }=7.1 \times 10^{-8} \mathrm{M} \mathrm{s}^{-1}$, $k_{\text {cat }}=V_{\max } /[\mathbf{1}]=1.77 \times 10^{-3} \mathrm{~s}^{-1} .2,4-\mathrm{BDNPP}$ bound to 1 hydrolyses approximately $10^{4}$ times faster than free 2,4-BDNPP $\left(k_{\text {unccat }}=1.8 \times 10^{-7} \mathrm{~s}^{-1}\right)$ [63] under the same conditions. Notably, the turnover number $\left(k_{\mathrm{cat}}\right)$ of $\mathbf{1}$ is approximately 2 times larger than that of the isostructural $\mathrm{Fe}^{\mathrm{III}} \mathrm{Zn}^{\mathrm{II}}$ complex, and approximately 3 times larger than that of the $\mathrm{Fe}^{\mathrm{III}} \mathrm{Mn}^{\mathrm{II}}$ homologue [34, 36]. Furthermore, the substrate is bound with a reduced affinity in $\mathbf{1}$ (judged by the relative $K_{\mathrm{m}}$ values of the three isostructural $\mathrm{Fe}^{\mathrm{III}} \mathrm{M}^{\mathrm{II}}$ complexes). In particular, when compared with that of the $\mathrm{Fe}^{\mathrm{III}} \mathrm{Mn}^{\mathrm{II}}$ complex the substrate binding affinity is reduced by approximately sixfold, which may indicate a different orientation of 2,4-BDNPP in 1 during catalysis.

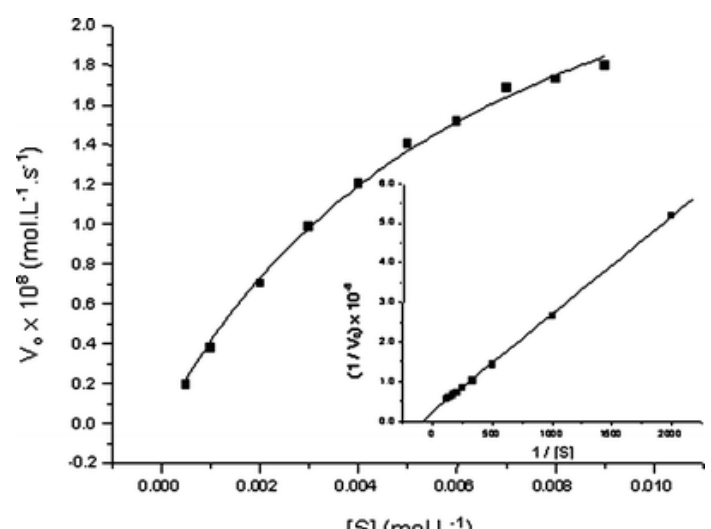

[S] $\left(\mathrm{molL}^{\mathrm{L}} \mathbf{1}^{-1}\right)$

Fig. 10 Dependence of the rate on the 2,4-bis (dinitrophenol)phosphate concentration in the reaction catalyzed by $\mathbf{1}\left[\mathrm{pH} 7.0\left(50 \mathrm{mM}\right.\right.$ MES; $\left.\left.I=0.1 \mathrm{M}\left(\mathrm{LiClO}_{4}\right)\right],[\mathbf{1}]=4 \times 10^{-5} \mathrm{M}, 25^{\circ} \mathrm{C}\right)$. Inset LineweaverBurk plot with $K_{\mathrm{m}}=1.1 \times 10^{-2} \mathrm{M}, V_{\max }=7.1 \times 10^{-8} \mathrm{M} \mathrm{s}^{-1}$

In recent years the search for small molecules that can mimic the catalytic function of nucleases has attracted much attention owing to their potential as synthetic restriction enzymes [56]. In particular, model complexes that avoid the generation of free radicals are of interest. Recently, it was shown that an $\mathrm{Fe}^{\mathrm{III}} \mathrm{Ni}^{\mathrm{iI}}$ complex, isostructural to 1, can bind tightly to plasmid DNA, although no data supporting hydrolytic cleavage of this substrate have been reported [33]. To verify the cleavage of nucleic acids by complex 1, plasmid DNA was incubated at $37^{\circ} \mathrm{C}$ for $18 \mathrm{~h}$ in $25 \mathrm{mM}$ MOPS buffer ( $\mathrm{pH}$ 7.2), at concentrations varying from 
2.5 to $320 \mu \mathrm{M}$, as indicated in Fig. 11. Under these experimental conditions the active [Fe ${ }^{\mathrm{III}}$ $(\mu) \mathrm{OH}-\mathrm{Cu}^{\mathrm{II}} \mathrm{OH}_{2}$ ] species of $\mathbf{1}$ should be present as established by potentiometric titration, mass spectrometry and 2,4-BDNPP hydrolysis (vide supra). Complex $\mathbf{1}$ is able to cleave plasmid DNA even at very low concentrations $(2.5 \mu \mathrm{M})$, under mild $\mathrm{pH}$ and temperature conditions. A clear increase in circular (nicked) plasmid DNA, and a proportional decrease in supercoiled DNA (form I) was observed. The estimated $\mathrm{EC}_{50}$ (the effective concentration promoting $50 \%$ cleavage of the substrate) for complex 1 in relation to plasmid DNA is $55 \mu \mathrm{M}$, one of the lowest values reported in the literature [66-68]. In addition, we have observed that the hydroxyl radical scavenges glycerol (Fig. 11, lane 10) and dimethyl sulfoxide (DMSO) (Fig. 11, lane 11) did not interfere with the DNA cleavage activity of complex 1, thus suggesting that diffusible hydroxyl radicals were not involved in the cleavage reaction. To verify whether a hydrolytic or an oxidative mechanism was involved in DNA cleavage by $\mathbf{1}$, assays were performed under anaerobic conditions. The absence of oxygen did not affect DNA cleavage by 1 (Fig. 12, lanes 2 and 8) and a hydroxyl radical scavenger, DMSO, does not seem to inhibit the reaction (Fig. 12, lanes 5 and 11). To test further the reaction mechanism a parallel experiment using the classical oxidative cleaving agent [Fe(EDTA)] ${ }^{2-}$ /dithiothreitol was performed under aerobic and rigorously anaerobic conditions. Under anaerobic conditions, no DNA degradation was observed (Fig. 12, lanes 3 and 9); the efficiency of DMSO as a radical scavenger can be observed in Fig. 12 (compare lanes 9 and 11). Complex 1 cleaves DNA even in the absence of oxygen (Fig. 12, lanes 2 and 8), approximately to the same extent as under aerobic conditions. It is thus concluded that complex $\mathbf{1}$ is likely to cleave DNA by a hydrolytic mechanism.

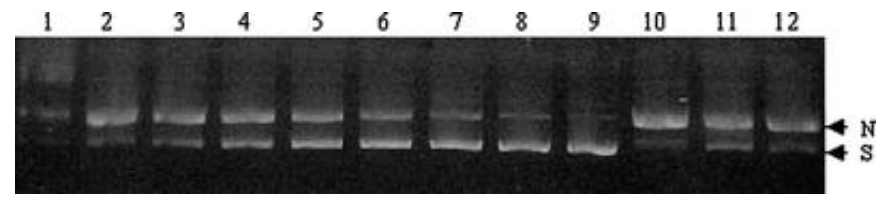

Fig. 11 Cleavage profile of pBSK II plasmid DNA [ $90 \mu \mathrm{M}$ (base pair), pH 7.2 at $37^{\circ} \mathrm{C}$ ) in the presence of increasing concentrations of $\mathbf{1}$. The concentrations $(\mu \mathrm{M})$ of $\mathbf{1}$ were $320,160,80,40,20,10$, 5, 2.5 and 0 (lanes 1-9, respectively). Nicked $(N)$ and supercoiled $(S)$ plasmid DNA are also depicted. Lanes 10 and 11 show $160 \mu \mathrm{M} 1$ in the presence of $0.5 \%$ glycerol and $20 \%$ dimethyl sulfoxide (DMSO), respectively. As a control untreated plasmid DNA is shown in lane 12.

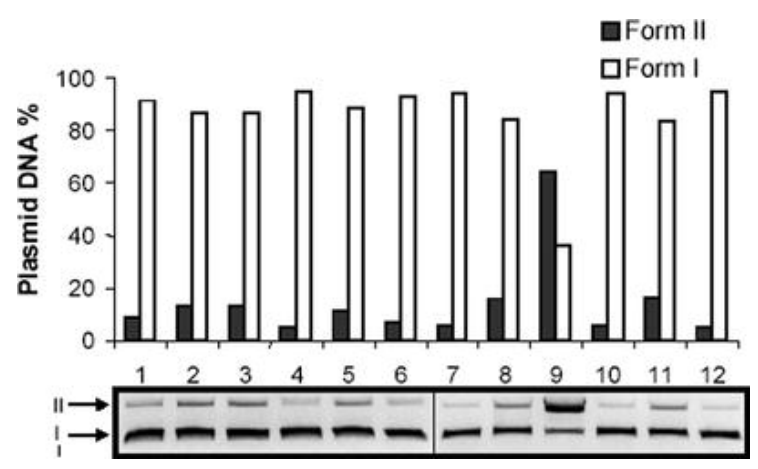

Fig. 12 Plasmid DNA cleavage in anaerobic (lanes 1-6) and aerobic conditions (lanes 7-12); in the absence (lanes 1-3 and 7-9) or presence (lanes 4-6 and 10-12) of DMSO. Lanes 1, 4, 7 and 10 plasmid DNA; lanes 2, 5, 8 and 11 plasmid DNA in the presence of $1(160 \mu \mathrm{M})$; lanes 3, 6, 9 and 12 plasmid DNA in the presence of $\mathrm{Fe}(\mathrm{EDTA})^{2-} /$ dithiothreitol. All reactions were incubated in $25 \mathrm{mM} 3-$ ( $N$-morpholino)propanesulfonic acid, $\mathrm{pH} 7.0$, in a final volume of $20 \mu 1$ at $37^{\circ} \mathrm{C}$ for $3 \mathrm{~h}$. The histogram shows the relative amounts of the two-plasmid DNA forms.

Kinetics studies of the DNA cleavage by 1 revealed that the decrease in supercoiled DNA fitted a single-exponential decay curve. Rates of cleavage at various concentrations of 1 (40- 
$640 \mu \mathrm{M})$ and a constant DNA concentration were calculated and a plot of $\mathrm{k}_{\text {obs }}$ versus the concentration of 1 shows saturation behavior (Fig. 13). Under these experimental conditions (pseudo-Michaelis-Menten conditions [66-68]) the kinetics parameters obtained from this plot were $k_{\text {cat }}^{\prime}=0.98 \mathrm{~h}^{-1}, K_{\mathrm{m}}=3.97 \times 10^{-5} \mathrm{M}$ and $k_{\text {cat }}^{\prime} / \mathrm{K}_{\mathrm{m}}=2.46 \times 10^{4} \mathrm{M}^{-1} \mathrm{~h}^{-1}$, providing a rate enhancement of $2.71 \times 10^{7}$ over the uncatalyzed double-stranded DNA cleavage. These values highlight complex 1 as one of the most active described to date, comparable to the $\mathrm{Cu}$ neamine complex described by Sreedhara and coworkers [66, 68].

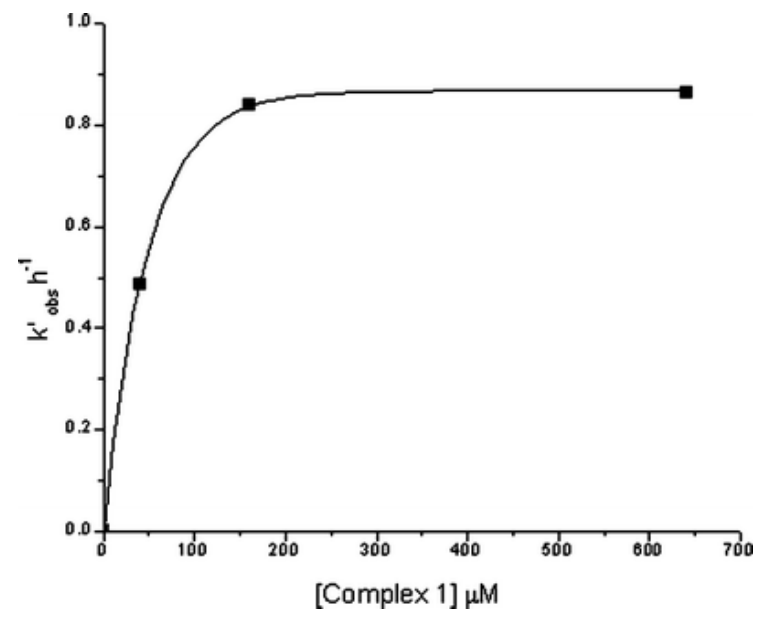

Fig. 13 Kinetics analysis of DNA cleavage promoted by $\mathbf{1}$. The concentrations of $\mathbf{1}$ were varied from 40 to $640 \mu \mathrm{M}$ in the presence of $90 \mu \mathrm{M}$ (base pair) pBSK II DNA.

\section{Conclusion}

The heterobinuclear complex 1 described herein displays high efficiency towards the activated substrate 2,4-BDNPP and, interestingly, is also very proficient in the cleavage of plasmid DNA under physiological conditions and at very low concentrations of $\mathbf{1}$, indicating its potential as a chemical nuclease. A combination of data from mass spectrometry, potentiometric titrations, X-ray absorption and EPR spectroscopy, as well as kinetics measurements indicate that in ethanol/water solutions an $\left[\mathrm{Fe}^{\mathrm{III}}-(\mu) \mathrm{OH}-\mathrm{Cu}^{\mathrm{II}} \mathrm{OH}_{2}\right]^{+}$species is generated which is the likely catalyst for the hydrolysis of 2,4-BDNPP and the cleavage of DNA. Insofar as the data are consistent with the presence of an $\mathrm{Fe}^{\mathrm{III}}$-bound hydroxide acting as a nucleophile during catalysis, 1 presents a suitable mimic for the hydrolytic enzyme PAP. Notably, $\mathbf{1}$ is significantly more reactive than its isostructural homologues with different metal composition ( $\mathrm{Fe}^{\mathrm{III}} \mathrm{M}^{\mathrm{II}}$, where $\mathrm{M}^{\mathrm{II}}$ is $\mathrm{Zn}^{\mathrm{II}}, \mathrm{Mn}^{\mathrm{II}}$, $\mathrm{Ni}^{\mathrm{II}}$ and $\mathrm{Fe}^{\mathrm{II}}$ ). Of particular interest was the observation that cleavage of double-stranded plasmid DNA occurred even at very low concentrations of $\mathbf{1}(2.5 \mu \mathrm{M})$, under physiological conditions (optimum $\mathrm{pH}$ 7.0), with a rate enhancement of $2.7 \times 10^{7}$ over the uncatalyzed reaction. Thus, $\mathbf{1}$ is one of the most effective model complexes to date mimicking the function of nucleases.

Acknowledgements Financial support was received from CNPq, PRONEX (Brazil). M.L. and P.C.S. are grateful to CNPq (Brazil) for a scholarship. XAS data collection was performed at the Australian National Beamline Facility with support from the Australian Synchrotron Research Program, which is funded by the Commonwealth of Australia under the Major National Research Facilities Program. We would also like to thank G. Foran and J. Hester for their help in data collection. We are grateful to the Australian Research Council for funding this research and for grants to purchase the EPR facilities.

\section{References}

1. Schenk G, Ge Y, Carrington LE, Wynne CJ, Searle IR, Carroll BJ, Hamilton S, de Jersey J (1999) Arch Biochem Biophys 370:183-189

2. Klabunde T, Krebs B (1997) Struct Bond (Berlin) 1:177-198 
3. Twitchett MB, Sykes AG (1999) Eur J Inorg Chem 12:2105-2115

4. Sträter N, Lipscomb WN, Klabunde T, Krebs B (1996) Angew Chem Int Ed 35:2024-2055

5. Merkx M, Averill BA (1998) Biochemistry 37:8490-8497

6. Campbell HD, Dionysius DA, Keough DT, Wilson BE, de Jersey J, Zerner B (1978) Biochem Biophys Res Commun 82:615-620

7. Marshall K, Nash K, Haussman G, Cassady I, Hume D, de Jersey J, Hamilton S (1997) Arch Biochem Biophys 345:230-236

8. $\quad$ Ljusberg J, Ek-Rylander B, Andersson G (1999) Biochem J 343:63-69

9. Ketcham CM, Roberts RM, Simmen RCM, Nick HS (1989) J Biol Chem 264:557-563

10. Halleen J, Hentunen TA, Hellman J, Väänänen HK (1996) J Bone Miner Res 11:1444-1452

11. Robinson DB, Glew RH (1980) J Biol Chem 255:5864-5870

12. Oddie GW, Schenk G, Angel NZ, Walsh N, Guddat LW, de Jersey J, Cassady AI, Hamilton SE, Hume DA (2000) Bone 27:575-584

13. Beck JL, McConaghie LA, Summors AC, Arnold WN, de Jersey J, Zerner B (1986) Biochim Biophys Acta 869:61-68

14. Durmus A, Eicken C, Sift BH, Kratel A, Kappl R, Hüttermann J, Krebs B (1999) Eur J Biochem 260:709716

15. Kostrewa D, Wyss M, D Arcy A, van Loon APGM (1999) J Mol Biol 288:965-974

16. Schenk G, Guddat LW, Ge Y, Carrington LE, Hume DA, Hamilton S, de Jersey J (2000) Gene 250:117125

17. Schenk G, Korsinczky MLJ, Hume DA, Hamilton S, de Jersey J (2000) Gene 255:419-424

18. Guddat LW, McAlpine AS, Hume DA, Hamilton S, de Jersey J, Martin J (1999) Structure 7:757-767

19. Lindqvist Y, Johansson E, Kaija H, Vihko P, Schneider G (1999) J Mol Biol 291:135-147

20. Uppenberg J, Lindqvist F, Svensson C, Ek-Rylander B, Andersson G (1999) J Mol Biol 290:201-211

21. Sträter N, Klabunde T, Tucker P, Witzel H, Krebs B (1995) Science 268:1489-1492

22. Klabunde T, Sträter N, Fröhlich R, Witzel H, Krebs B (1996) J Mol Biol 259:737-748

23. Schenk G, Carrington LE, Hamilton SE, de Jersey J, Guddat LW (1999) Acta Cryst D55:2051-2052

24. Schenk G, Gahan LR, Carrington LE, Valizadeh M, Hamilton SE, de Jersey J, Guddat LW (2004) Proc Natl Acad Sci USA 102:273-278

25. Twitchett MB, Schenk G, Aquino MAS, Yiu DTY, Lau TC, Sykes AG (2002) Inorg Chem 41:5787-5794

26. Beck JL, Keough DT, de Jersey J, Zerner B (1984) Biochim Biophys Acta 791:357-363

27. Beck JL, McArthur MJ, de Jersey J, Zerner B (1988) Inorg Chim Acta 153:39-44

28. Beck JL, Durack MCA, Hamilton SE, de Jersey J (1999) Inorg Biochem 73:245-252

29. Merkx M, Averill BA (1999) J Am Chem Soc 121:6683-6689

30. Schenk G, Boutchard CL, Carrington LE, Noble CJ, Moubaraki B, Murray KS, de Jersey J, Hanson GR, Hamilton S (2001) J Biol Chem 276:19084-19088

31. Wilcox DE (1996) Chem Rev 96:2435-2458

32. Valizadeh M, Schenk G, Nash K, Oddie GW, Guddat LW, Hume DA, de Jersey J, Burke TR Jr, Hamilton S (2004) Arch Biochem Biophys 424:154-162

33. Batista SC, Neves A, Bortoluzzi AJ, Vencato I, Peralta RA, Szpoganicz B, Aires VVE, Terenzi H, Severino PC (2003) Inorg Chem Commun 6:1161-1165

34. Karsten P, Neves A, Bortoluzzi AJ, Lanznaster M, Drago V (2002) Inorg Chem 41:4624-4626

35. Karsten P, Neves A, Bortoluzzi AJ, Strähle J, Maichle-Mössmer C (2002) Inorg Chem Commun 5:434438

36. Lanznaster M, Neves A, Bortoluzzi AJ, Szpoganicz B, Schwingel E (2002) Inorg Chem 41:5641-5643

37. Neves A, de Brito M, Vencato I, Drago V, Griesar K, Haase W (1996) Inorg Chem 35:2360-2368

38. Neves A, de Brito MA, Drago V, Griesar K, Haase W (1995) Inorg Chim Acta 237:131-135

39. Holman T, Andersen KA, Anderson OP, Hendrich MP, Juarez-Garcia C, Münck E, Que L Jr (1990) Angew Chem Int Ed 29:921-923

40. Belle C, Gautier-Luneau I, Gellon G, Pierre JL, Morgenstern-Badarau I, Saint-Aman E (1997) J Chem Soc Dalton Trans 3543-3546

41. Ghiladi M, McKenzie CJ, Meier A, Powell AK, Ulstrup J, Wocadlo S (1997) J Chem Soc Dalton Trans 21:4011-4018

42. Ghiladi M, Jensen KB, Jiang J, McKenzie CJ, Morup S, Sotofte I, Ulstrup J (1999) J Chem Soc Dalton Trans 2675-2681

43. Spek AL (1996) HELENA: CAD-4 data reduction program. University of Utrecht, The Netherlands

44. Spek AL (1997) PLATON: molecular geometry and plotting program. University of Utrecht, The Netherlands

45. Sheldrick GM (1990) SHELXS97: program for the solution of crystal structures. University of Göttingen, Germany

46. Sheldrick GM (1997) SHELXL97: program for the refinement of crystal structures. University of Göttingen, Germany

47. Zsolnai L (1997) ZORTEP: an interactive ORTEP program. University of Heidelberg, Germany

48. Martell AE, Motekaits RJ (1992) Determination and use of Stability constants. VCH Publishers, New York

49. Gagne RR, Koval CA, Lisensky GC (1980) Inorg Chem 19:2854-2855

50. Ravel B (2001) J Synchrotron Rad 8:314-316

51. Rehr JJ, Mustre de Leon J, Zabinsky SI, Albers RC (1991) J Am Chem Soc 113:5135-5140 
52. Newville M (2001) J Synchrotron Rad 8:322-324

53. Hanson GR, Gates KE, Noble CJ, Griffin M, Mitchell A, Benson S (2004) J Inorg Biochem 98:903-916

54. Rossi LM, Neves A, Hörner R, Terenzi H, Szpoganicz B, Sugai J (2002) Inorg Chim Acta 337:366

55. Neves A, Terenzi H, Hörner R, Horn A Jr, Szpoganicz B, Sugai J (2001) Inorg Chem Commun 4:388-391

56. Scarpellini M, Neves A, Hörner R, Bortoluzzi AJ, Szpoganicz B, Zucco C, Silva RAN, Drago V, Mangrich AS, Ortiz WA, Passos WAC, Oliveira MCB, Terenzi H (2003) Inorg Chem 42:8353-8365

57. Lambert E, Chabut B, Chardon-Noblat S, Deronzier A, Chottard G, Bousseksou A, Tuchagues JP, Laugier J, Bardet M, Latour JM (1997) J Am Chem Soc 119:9424-9437

58. Westre TE, Kennepohl P, DeWitt JG, Hedman B, Hodgson KO, Solomon EI (1997) J Am Chem Soc 119:6297-6314

59. Roe AL, Schneider DJ, Mayer RJ, Pyrz JW, Widom J, Que L (1984) J Am Chem Soc 106:1676-1681

60. Juarez-Garcia C, Hendrich MP, Holma TR, Que L, Munck E (1991) J Am Chem Soc 113:518-525

61. Smith TD, Pilbrow JR (1974) Coord Chem Rev 13:173-278

62. Dessens SE, Merrill CL, Saxton RJ, Ilaria RL Jr, Lindsey JW, Wilson LJ (1982) J Am Chem Soc 104:4357-4361

63. Bunton CA, Farber SJ (1969) J Org Chem 34:767-772

64. Aquino MAS, Lim JS, Sykes AG (1994) J Chem Soc Dalton Trans 429-436

65. Smoukov SK, Quaroni L, Wang X, Doan PE, Hoffman BM, Que L Jr (2002) J Am Chem Soc 124:25952603

66. Sreedhara A, Freed JD, Cowan JA (2000) J Am Chem Soc 122:8814-8824

67. Cowan JA (2001) Curr Opin Chem Biol 5:634-642

68. Sreedhara A, Cowan JA (2001) J Biol Inorg Chem 6:337-347 